United States Department of the Interior

Geological Survey

\title{
GEOCHEMISTRY AND PETROLOGY OF BASALTIC ROCKS \\ FROM THE MARSHALL ISLANDS
}

by

Alice S. Davis ${ }^{1}$, William C. Schwab ${ }^{2}$ and Janet A. Haggerty ${ }^{3}$

Open File Report 86-273

This report is preliminary and has not been reviewed for conformity with the U.S. Geological Survey editorial standards and stratigraphic nomenclature.

Menlo Park, California

1986

${ }^{1}$ Menlo Park, CA

${ }^{3}$ Univ. of Tulsa, OK

${ }^{2}$ Woods Hole, MA 


\section{INTRODUCTION}

A variety of volcanic rock was recovered from the flanks of seamounts, guyots, atolls, and islands in the Ratak chain of the Marshall Islands on the U.S. Geological Survey cruise L984-CP. The main objective of this cruise was to study the distribution and composition of ferromanganese oxide crusts. Preliminary results of managanese crust composition are reported by Schwab et al. (1985) and detailed studies are in preparation (Schwab et al., 1986).

A total of seven seafloor edifices were studied using $12 \mathrm{khz}, 3.5 \mathrm{khz}$ and air gun seismic reflection, chain dredge and box corer. Bathymetry and ship track lines are presented by Schwab and Bailey (1985). Of the seven edifices surveyed two support atolls (Majuro and Taongi) and one is a tiny island (Jemo). Dredge locations and water depths are given in Table 1 and dredge locations are shown in Figure 1. Due to equipment failures depths of dredge hauls were limited to shallow depth for all except the first two sites occupied. Recovery consisted mostly of young, poorly-consolidated limestone of fore-reef slope deposit and minor volcanogenic breccia and loose talus. The breccia and pieces of talus are thickly encrusted with ferromanganese oxide, whereas the young limestone is only coated by a thin layer. Four of the seven sites surveyed yielded volcanic rock. The volcanic rock, volumetrically a minor part of each dredge haul, consists mostly of lapilli and cobble-size clasts in a calcareous matrix or as loose talus. Most clasts show evidence of reworking, being sub- to well rounded, sometimes with a thin ferromanganese crust of their own.

This paper reports preliminary findings on the petrology and geochemistry of volcanic rock recovered.

\section{ANALYTICAL METHODS}

Lithologically representative samples were studied in thin sections, and alteration phases were verified by $x$-ray diffraction. The least altered material of larger clasts was selected for chemical analyses. The alteration rims and veinlets of secondary minerals were trimmed off with a water-cooled diamond saw. The selected chips were treated with dilute acetic acid to remove $\mathrm{CaCO}_{3}$ and repeatedly washed with distilled water to eliminate traces of salt, and then oven-dried $\left(<100^{\circ} \mathrm{F}\right)$. Major element chemistry was determined by $x$-ray fluorescence in the analytical laboratory of the U.S.G.S. in Denver. Wet chemical analyses for $\mathrm{FeO}, \mathrm{CO}_{2}$, $\mathrm{H}_{2} \mathrm{O}^{+}$, and $\mathrm{H}_{2} \mathrm{O}^{-}$, as well as energy dispersive $\mathrm{XRF}$ analyses of $\mathrm{Rb}, \mathrm{Sr}, \mathrm{Zr}, \mathrm{Ba}, \mathrm{Y}$, and $\mathrm{Nb}$ were performed in the analytical laboratory of the U.S.G.S. in Menlo Park. The abundance of Hf, $\mathrm{Ta}, \mathrm{Th}$, and the rare earth elements (REE) were determined by neutron activation analysis (INNA) in the analytical laboratory of the U.S.G.S. in Reston. Mineral chemistry of plagioclase, clinopyroxene, and titanomagnetite were determined on a 9 channel ARL SEMQ electron microprobe at the U.S.G.S. in Menlo Park. Clinopyroxene and titanomagnetite were analyzed using $15 \mathrm{kv}, 20 \mathrm{nAmps}$, and a narrowly focused beam $(\sim 1 \mu)$, whereas plagioclase were analyzed using $10 \mathrm{nAmps}$ and a defocused beam $(\sim 10 \mu)$ to avoid burning off sodium. Natural and synthetic oxides and minerals were used as standards. Data reduction was performed using a modified version of Bence and Albee (1968). 


\section{PETROGRAPHY AND MINERALOGY}

Petrographic data are summarized in Table 2 and chemistry of plagioclase, clinopyroxene and titanomagnetite are given in Tables 5,6 , and 7 respectively.

\section{Majuro Atoll}

The volcanic rock recovered from the flanks of the volcanic edifice supporting the Majuro Atoll consists predominantly of differentiated alkali olivine basalt fragments in a well-indurated, pale-beige phosphatized limestone matrix. Chemically the basalts are transitional between alkali olivine basalt and hawaiite. Two lithologies appear to be present. Samples of dredge 1 are highly angular, red-brown oxidized wedges with yellow-golden palagonite rims. The rock is hyalopilitic and seriate rather than porphyritic, showing a progression of crystal sizes from microlites $(<1 \mu)$ to larger crystals $(\sim 1 \mathrm{~mm})$ of euhedral plagioclase, olivine and clinopyroxene in a non-vesicular glass matrix. The olivine is completely replaced by bright red iddingsite. The olivine crystals are elongated and show a pronounced alignment indicating flow direction. The clinopyroxene is unaltered, gray to very pale brownish augite $\left(2 \mathrm{~V} \sim 50^{\circ}\right)$ with compositional zoning very minor or absent. Plagioclase is also unaltered, sodic labradorite to andesine in composition, and shows no optical zoning or disequilibrium textures. One larger crystal (1-1\#5) shows some reverse zoning with a rim of An 53-Or 1.7 and a core of An 47.8-Or 2.4. Opaques are abundant, sub- to euhedral crystals of titanomagnetite that have been largely oxidized. The glass is altered to yellow-golden palagonite or oxidized to a reddish-brown. Small areas of pale-brown sideromelane are still present but could not be analyzed due to abundant crystallites.

A second lithology is represented by one sub-rounded clast $(\sim 10 \mathrm{~cm})$ from dredge 3 . It is similar in mineralogy to those of dredge 1 except its groundmass is more tachylitic with subtrachytic texture. Olivine is slightly more abundant, and instead of iddingsite, pseudomorphed by smectite with an iddingsite rim. Clinopyroxene is unaltered salitic augite similar to those of dredge 1. Larger crystals show slight reverse zoning, with cores more iron-rich than the rims. Plagioclase is somewhat more calcic than in D1, and all crystals analyzed are labradorite ranging from An 56.9 to An 58.2. Titanomagnetite is similar in composition to that in samples from D1. No ilmenite or rutile exsolution lamellae were observed in either lithology.

The abundance of glass in rocks from dredge 1 indicate rapid quenching in water. The wedge-shaped pieces, with yellow palagonite rinds, signs of autobrecciation, and contact rims of well-crystallized zeolites grading into the calcareous sediment indicate contact of hot lava with wet sediment. Such rocks consisting of dark basaltic fragments in a light-colored limey matrix, formed by eruption into wet sediment have been called peperites (Fisher and Schmincke, 1984). The combination of bright-red iddingsite replacing olivine and the absence of vesicles may suggest subaerial eruption. Although absence of vesicles may be indicative of either an undegassed lava erupting in deep water, or a subaerially degassed lava. The flow may have originated subaerially but flowed into water. The sub-rounded tachylite cobble of dredge 3 suggests subaerial eruption followed by erosion.

Foraminifers in the calcareous matrix of D1 have tentatively been identified as Cretaceous in age.

\section{Erikub Seamount}


The volcanic rock recovered from a seamount informally referred to as Erikub Seamount consists of heterolithologic tuff breccia and loose angular pieces of hawaiite. The tuff breccia consists of poorly sorted, angular to rounded lithic clasts ranging from $<1 \mathrm{~cm}$ to $30 \mathrm{~cm}$ in size, minor vesicular palagonite fragments, and broken clinopyroxene crystals in a phosphatized biomicrite matrix. The lithic clasts appear to represent at least six different lithologies. Two kinds of alkali olivine basalt appear to be present: one type (D6-16) is nonvesicular, and sparsely plagioclase-pyroxene phyric, the second type (D6-18), also nonvesicular, is olivine-plagioclase-pyroxene phyric with rapidly quenched skeletal opaques (ilmenite?) in the groundmass. Three lithologies transitional between alkali basalt and hawajite are represented: One type (D4-2) is moderately vesicular, sparsely plagioclase-phyric, the second type (D4-3) is non-vesicular, sparsely plagioclase-phyric, and the third type (D6-24) is moderately to highly vesicular tachylite with a pronounced trachytic texture. The sixth lithology (D6-1), volumetrically the most abundant, is essentially aphyric to very sparsely plagioclase phyric $(<1 \%)$ hawaiite almost wholly composed of andesine microlites with minute granules of clinopyroxene, and small amounts $(<4 \%)$ of yellow-brown chlorite (?) possibly replacing biotite. The olivine is completely replaced in all samples by smectite with iddingsite rims. The clinopyroxene is unaltered, pale-gray to pale brown augite and salite. $\mathrm{TiO}_{2}$ in the clinopyroxene ranges from a low of 0.93 in the rim of a rounded phenocryst (D6-17\#1) to a high of 2.98 in a euhedral groundmass crystal (D6-18\#1). Compositional zoning is minor, and may be normal or reverse. The plagioclase ranges from An 83.7 in the alkali olivine basalt of D6-17 to An 40.7 in the hawaiite of D6-1. The rare phenocrysts of plagioclase and clinopyroxene present in D4-2 and D6-18 show minor compositional zoning and disequilibrium features, whereas the groundmass crystals are euhedral and homogeneous.

The presence of well-rounded clasts, sometimes surrounded by a thin ferromanganese oxide crust, the presence of intraclasts of biomicrite, and the poor sorting indicate that these breccias are sediment gravity flow deposits. However, some portions of the breccia, especially those with abundant broken crystals, have a zeolitized matrix that may be replacing ash, suggesting a subaqueous pyroclastic flow origin for some clasts and later reworking by sediment gravity flows. The abundance of highly vesicular tachylitic lapilli, oxidized hawaiites, and well-rounded heterolithologic clasts indicate subaerial eruption and erosion before final deposition as submarine debris flows and slumps. Foraminifers in the biomicrite have been tentatively identified as Cretaceous in age.

\section{Bikar Guyot}

The volcanic rock recovered from the eastern flank of a guyot informally referred to as Bikar Guyot consists of a few well-rounded, oxidized, lithic clasts $(<6 \mathrm{~cm})$ and extremely altered palagonite with minor amounts of broken clinopyroxene crystals in a zeolitized biomicrite matrix. The rounded lithic clasts, constituting less than $2 \%$ of the breccia, are wellrounded, highly vesicular $(\sim \mathbf{4 0 \%})$, ankaramitic alkalic basalt. The rock is highly porphyritic $(>25 \%)$ with microphenocrysts of a yellow-green, highly birefringent, $\mathrm{Mg}$-rich clay (saponite?) apparently replacing olivine and pyroxene. Some euhedral crystal outlines of olivine and pyroxene are identifiable but proportions of each are difficult to estimate. Iron oxides and smectites are also replacing most of the groundmass crystals. Only a few cores of unaltered clinopyroxene remain. Analysis of these cores showed them to be salites somewhat higher in $\mathrm{Ca}$ and $\mathrm{Al}$ than clinopyroxene in all of the other samples from the southern sites. Even the plagioclase is completely replaced by clay minerals. The vesicles are lined with a $\mathrm{Mg}$-rich clay (saponite?), and have cores of carbonate-phosphate. The second lithology is represented only by extremely altered, vesicular palagonite fragments, mixed with broken clinopyroxene crystals, in a zeolite tuff matrix. The great abundance of vesicles and vesicular palagonite suggests eruption into shallow water. 


\section{Ratak Guyot}

Volcanic rock recovered from a guyot informally referred to as Ratak Guyot consists predominantly of angular fragments of hawaiite (D18) and a few cm-sized clasts of highly altered alkali olivine basalt in a phosphatized biomicrite matrix (D17). The hawaiite is darkgray, extremely fine-grained, aphyric with irregularly shaped vugs $(\sim 10 \%)$ filled with zeolites. The hawaiite consists of plagioclase microlites showing a pronounced trachytic texture in an almost opaque matrix $(<10 \%)$. Tiny granules of clinopyroxene are present in the groundmass, as well as rare $(<2 \%)$ microphenocrysts $(\sim 100 \mu)$ of oxidized titanomagnetite. Iron oxides line all fractures. The alkalic basalt is represented by rare, non-vesicular clasts to $1 \mathrm{~cm}$ in size with clinopyroxene microphenocrysts $(<0.5 \mathrm{~mm})$. The clasts are well-rounded, extremely altered to iron hydroxides and clay. Only a few cores of clinopyroxene crystals are still fresh.

The pervasive oxidation of the hawaiites and roundness of the altered basalt clasts suggest weathering and erosion of subaerially erupted lavas, before final deposition as sediment gravity flow deposits.

Foraminifers in biomicrite have been tentatively identified as early Tertiary in age. However, since there is no evidence of subaqueous eruption the lavas may predate the biomicrite.

\section{MAJOR ELEMENT CHEMISTRY}

Major element composition was determined for eleven samples and data are presented in Table 3. All of the samples are at least somewhat altered. The hawaiites are the least altered, as evidenced by total water content of less than $3 \%$. The most severely altered sample from Bikar Guyot (D15) shows a total water content of $8.50 \%$. Alteration appears to have affected most severely the $\mathrm{MgO}$ and $\mathrm{FeO}$ content of samples that had abundant olivine which was replaced by iddingsite or by a combination of smectite and iddingsite. Alteration of hawaiites resulted mostly in oxidizing the opaques, resulting in an excessive amount of $\mathrm{Fe}_{2} \mathrm{O}_{3}$. Normative calculations of altered rocks are of limited value, nevertheless some indication of the degree of undersaturation may be obtained. CIPW norms were calculated with iron adjusted to $\mathrm{Fe}_{2} \mathrm{O}_{3} / \mathrm{FeO}=0.2$, and are shown in Table 3. Calculating CIPW norms without an adjustment for iron oxidation results in quartz-normative compositions for all except the hawaiites from D18. With iron adjusted, all samples are olivine-normative and hawaiites from D18 and D6-1 are nepheline-normative.

Alkalies appear to be less sensitive to alteration in alkalic basalt, and alkali abundance is probably representative, as long as great care is taken in excluding zeolite-rich material. However, when even the feldspar is altered, as is the case for D15, even the alkalies are suspect. The dredged lavas are shown on an alkalies versus silica diagram in Figure 2, and all plot in the alkalic field (Macdonald and Katsura,1964). The extremely altered sample of D15 appears strongly undersaturated like basanite or nephelinite, but low silica content may be the result of alteration. The volcanic rocks from the Marshall Islands range from alkalic basalt to hawaiites. No mugearites or trachytes were recovered. Not enough samples were recovered to establish differentiation trends for the individual sites. However, compositions of D15 and D18 suggest a more alkalic trend for the two northern sites. The Marshall Island lavas appear to be similar to mildly and moderately alkalic lavas of Samoa (Natland, 1976) and Hawaii (Macdonald, 1968). They are also similar to alkalic lavas from the Line Islands (Natland, 1976), but show none of the unusual compositions, such as potassic nephelinites, 
that have been recovered from some seamounts in the Line Island chain.

Another element that appears to be sensitive to alteration processes at seamounts in tropical waters is phosphorus. A plot of $\mathrm{P}_{2} \mathrm{O}_{5}$ versus $\mathrm{TiO}_{2}$ (Fig. 3) shows considerable scatter exists for samples that trace element and lithologic features identify as the same flow unit (e.g. 18-8 and 18-5). Careful examination of thinsections failed to give an optical indication of phosphorus enrichment due to alteration, which would allow selection of less altered material for chemical analysis.

\title{
TRACE ELEMENT CHEMISTRY
}

\begin{abstract}
Abundances of nineteen trace elements, including the rare earth (REE), were determined for ten samples and are presented in Table 4. The chondrite-normalized REE patterns are shown in Figure 4. The normalized REE plots of the Marshall Island lavas have steep slopes with light rare earth element enrichment over heavy rare earth elements that is typical of alkalic rocks in general, and are similar to more evolved alkalic lavas from Hawaii (Basaltic Volcanism Project, 1981). La ranges from 100 times chondrites in the least differentiated alkalic basalt (D6-18) to 270 times chondrites in the hawaiites from the northernmost seamount (D18). The highly altered sample from dredge 15 has La 370 times chondrite, suggestive of a strongly alkalic composition, but that may be the result of alteration. Submarine weathering and burial metamorphism can result in selective enrichment of light rare earth elements over heavy rare earth (Ludden and Thompson, 1979; Hellman et al., 1979). Phosphatization appears to result in gross REE enrichment (Clague, unpublished data). Yb shows a narrower range with abundances ranging from 10 to 17 times chondrites.
\end{abstract}

Incompatible elements such as $\mathrm{Rb}, \mathrm{Ba}, \mathrm{Sr}, \mathrm{Ti}, \mathrm{Y}, \mathrm{Zr}, \mathrm{Nb}$ are concentrated in the residual alkalic liquid during fractionation. Hence, they should show a progressive increase with differentiation. The Marshall Island lavas show a general increase in these elements from alkali olivine basalt to hawaiite but considerable scatter is evident. $\mathrm{Rb}, \mathrm{Ba}$, and $\mathrm{Sr}$ are easily mobilized by secondary alteration processes, whereas high field strength elements such as $\mathrm{Zr}$ and $\mathrm{Nb}$ are more alteration resistant (e.g. Pearce and Cann, 1973). Whereas $\mathrm{Zr}$ and $\mathrm{Nb}$ abundances increase with differentiation, $\mathrm{Zr} / \mathrm{Nb}$ ratios are not significantly changed by crystal fractionation. Lavas from the two southern sites have $\mathrm{Zr} / \mathrm{Nb}$ ratios of $5.2 \pm 0.3$, whereas the two northern sites have $\mathrm{Zr} / \mathrm{Nb}$ ratios of $3.0 \pm 0.2$, possibly suggesting a different mantle source. $\mathrm{La} / \mathrm{Sm}, \mathrm{Ce} / \mathrm{Yb}$, and $\mathrm{La} / \mathrm{Yb}$ ratios of lavas from the northern sites are significantly higher suggesting a more alkaline trend.

\section{DISCUSSION}

The volcanic rocks recovered from the Marshall Islands are alkalic basalt and hawaiites that were erupted subaerially and in shallow water. They are chemically similar to basalt and basaltic differentiates of Hawaiian lavas erupted during the post-shield stage. Hawaiian postshield lavas are late in the eruptive sequence forming mostly thin alkalic caps on big shields composed of tholeiitic basalt. Two main differentiation trends exist. The Kohala trend has mugearites as the predominant differentiate, whereas hawaiites are the predominat differentiate of the Haleakala trend (Macdonald, 1968). Both trends are shown for comparison on Figure 2. No tholeiitic rock was dredged from the seamounts in the Marshall Islands. Since dredging was generally limited to less than $2000 \mathrm{~m}$, it seems likely that the shield stage 
eruptions were not sampled. However, voluminous tholeiitic shields typical of Hawaiian volcanoes do not appear to be present on many volcanic islands in the South Pacific and South Atlantic Ocean. Islands in the Samoan and Caroline Island chains in the South Pacific or St.Helena and Ascenion in the South Atlantic appear to erupt only transitional and mildly alkalic basalts during the shield-building stage (Natland, 1976; Mattey, 1982; Baker, 1973). It may be that during the shield-building stage Marshall Island volcanoes also erupted only alkalic rock. A mildly alkalic composition as that of D6-18 could have erupted during the shield-building stage as well as during the post-shield stage.

Hawaiian volcanoes have a final eruption phase of alkalic to strongly alkalic lavas occurring after a period of dormancy that may span several millions of years. During this stage, known as the post-erosional stage, very small volumes of basanites, nephelinites, and rarer nepheline melilitites are erupted. The extremely altered sample (D15-5) from Bikar Guyot may be a strongly alkalic lava equivalent to those erupted during post-erosional volcanism in Hawaiian volcanoes. Clinopyroxene compositions with a Wo component (molar $\mathrm{Ca}$ ) of greater than 50 occur in Hawaii only in nephelinic lavas (Fodor et al., 1975). Since the clinopyroxene cores of D15-5 are still unaltered, clinopyroxene composition is probably a more reliable indicator than major and trace element abundances. No strongly alkalic lavas were recovered from the other sites in the Marshall Islands, suggesting that either post-erosinal volcanism did not occur here, or more likely, since the volume of post-erosional lavas is very small, that it just was not sampled.

Marshall Island lavas have higher $\mathrm{T} i$ and lower $\mathrm{Ba}$ than Hawaiian alkalic lavas, and generally show greater similarity with alkalic lavas from islands in the South Atlantic, such as Ascencion and St.Helena (Fig.5). Two different trends, or sources, are indicated for Marshall Island lavas. The two southern seamounts appear to have differentiated from a similar mantle source with $\mathrm{Zr} / \mathrm{Nb}$ of $5.2 \pm 0.3$, whereas the two northern seamounts show a slightly more alkalic trend with a $\mathrm{Zr} / \mathrm{Nb}$ of $3.0 \pm 0.2$. Higher $\mathrm{La} / \mathrm{Sm}, \mathrm{La} / \mathrm{Yb}$, and $\mathrm{Ce} / \mathrm{Yb}$ ratios also suggest a more alkaline trend for the northern sites. In the Society (Dostal et al., 1982) and Caroline Islands (Mattey, 1982) increasingly alkaline character of lavas has been linked to progressively decreasing age of islands within the chain. Not enough samples were recovered from the Marhall Islands to establish geochemical trends. However, detailed radiometric age dating studies of hawaiites from D6 and D18 are in progress that should determine if the Marshall Islands show any age progression. 


\section{REFERENCES CITED}

Baker, P. E., 1973, Islands of the South Atlantic. in Nairn, A. E. and F. G. Stehli (eds.); Ocean basins and margins, v. 1, The South Atlantic, p. 493-553.

Basaltic Volcanism Project, 1981, Basaltic volcanism on the terrestrial planets. Pergamon Press Inc.,New York.

Bass, M. N., Moberly, R., Rhodes,M. J., and Shih, C., 1973, Volcanic rocks cored in the central Pacific, Leg 17. in Winterer, E. L., J. I. Ewing et al. (eds.); Initial Reports of the Deep Sea Drilling Project, v. 17, p.429-503, U. S. Government Printing Office, Washington.

Bence, A. E. and Albee, A. E.,1968, Empirical correction factors for the electron microanalysis of silicates and oxides. J. Geol., 76, p.382-403.

Dostal, J., Dupuy, C., and Liotard, J. M., Geochemistry and origin of basaltic lavas from Society Islands, French Polynesia, South Central Pacific Ocean. Bull. Volcanol., 45, p.51-62.

Fisher, R. V. and Schmincke, H. U., 1984, Pyroclastic rocks. Springer Verlag, Berlin and Heidelberg, $472 \mathrm{p}$.

Fodor, R. V., Keil, K., and Bunch, T. E., 1975, Contributions to the mineral chemistry of Hawaiian rocks. Contrib. Min. Petrol., 50, p.173-195.

Hellman, P. L., Smith R. E. ,and Henderson, P., 1979, The mobility of the rare earth elements: evidence and implications from selected terrains affected by burial metamorphism. Contrib. Min. Petrol., 71, p.23-44.

Ludden, J. N. and Thompson, G., 1979, An evaluation of the behavior of the rare earth elements during the weathering of sea-floor basalt. Earth and Plan. Sci. Lett., 43, p.85-92.

Macdonald, G. A., 1968, Composition and origin of Hawaiian lavas. in Coats, R. E., Hay, R. L., and Anderson, C. A. (eds.). Studies in volcanology. Geol. Soc. Am. Memoir, 116, p.477-522.

Macdonald, G. A. and Katsura, T., 1964, Chemical composition of Hawaiian lavas. J. Petrol., 5, p.82-133.

Mattey, D. P., 1982, The minor and trace element geochemistry of volcanic rocks from Truk, Ponape and Kusaie, Eastern Caroline Islands; the evolution of a young hot spot trace across old Pacific crust. Contrib. Min. Petrol., 80, p.1-13.

Natland, J. H., 1976, Petrology of volcanic rocks dredged from seamounts in the Line Island chain. in Schlanger, and E. D. Jackson et al. (eds.) Initial Reports of the Deep Sea Drilling Project, v. 33, p.749-777. U.S. Government Printing Office, Washington.

Pearce, J. A. and Cann, J. R., 1973, Petrogenetic implications of $\mathrm{Ti}, \mathrm{Zr}$, Y, and $\mathrm{Nb}$ variations in volcanic rocks. Contrib. Min. Petrol., 69, p.23-47.

Schwab, W. C. and Bailey, N. G., 1985, High resolution seismic-reflection data collected on 
L9-84-CP, Marshall Islands to Hawaii. U.S. Geological Survey Open File Report, 85-24, 6p.

Schwab, W. C., Davis, A. S., Haggerty, J. A., Ling, T., and Commeau, J., 1985, Geologic reconnaissance and geochemical analyses of ferromanganese crusts of the Ratak chain, Marshall Islands. U. S. Geological Survey Open File Report, 85-18, 6 pages.

Schwab, W. C., Hein, J. R., Davis, A. S., Morgenson, L. A., and Daniel, C. L., 1986, Geologi$\mathrm{cal}$ and geochemical data for seamounts and associated ferromanganese crust in the Ratak chain, Marshall Islands. U. S. Geological Survey Open File Report, 86-xxx. 


\begin{tabular}{|c|c|c|c|c|}
\hline Sample No. & $\begin{array}{l}\text { Latitude } \\
\text { (N) }\end{array}$ & $\begin{array}{l}\text { Longitude } \\
\text { (E) }\end{array}$ & $\begin{array}{l}\text { Water Depth } \\
\text { (m) }\end{array}$ & Major Litholocies \\
\hline $\begin{array}{c}\text { D1 } \\
\text { Majuro } \\
\text { Atoll }\end{array}$ & $7 \cdot 15.0$ & $171 \cdot 00.6$ & $2250-2230$ & $\begin{array}{l}\text { broken pillow breceia of oxidized } \\
\text { alkali olivine basalt in phospha- } \\
\text { tised chalk matrix }\end{array}$ \\
\hline $\begin{array}{c}\text { D2 } \\
\text { Majuro } \\
\text { Atoll }\end{array}$ & $7 \cdot 14.1$ & $171 \cdot 00.3$ & $1480-1500$ & $\begin{array}{l}\text { poorly indurated limestone co- } \\
\text { quina of fore-reef slope deposit }\end{array}$ \\
\hline $\begin{array}{l}\text { D8 } \\
\text { Majuro } \\
\text { Atoll }\end{array}$ & $7 \cdot 15.5$ & $170 \cdot 59.1$ & $2000-3100$ & $\begin{array}{l}\text { rounded clast of limestone coqui- } \\
\text { na and sub-angular alkalic basalt } \\
\text { fracment }\end{array}$ \\
\hline $\begin{array}{l}\text { D4 } \\
\text { Erikub } \\
\text { Seamount }\end{array}$ & $8^{\circ} 44.8$ & $160^{\bullet} 14.3$ & 3550 & $\begin{array}{l}\text { beterolithologic tuf breceia } \\
\text { with alkalic basalt, highly vo- } \\
\text { sicular tachylite, palagonite and } \\
\text { broken cryatals in chalk matrix }\end{array}$ \\
\hline $\begin{array}{c}\text { D6 } \\
\text { Erikub } \\
\text { Seamount }\end{array}$ & $8^{\cdot} 45.3$ & $160^{\bullet} 47.5$ & 2900 & $\begin{array}{l}\text { ancular fragments of hawaiite } \\
\text { and alkalic basalt clasts in phos- } \\
\text { phatized chalk; tuf breceis with } \\
\text { broken cryatals and palaconite } \\
\text { and minor bioturbated chalk and } \\
\text { calcarenite }\end{array}$ \\
\hline $\begin{array}{l}\text { D10 } \\
\text { Jemo } \\
\text { Island }\end{array}$ & $10^{\circ} 005.1$ & $100 \cdot 36.6$ & $1000-1680$ & foro-reef limestone coquina \\
\hline $\begin{array}{c}\text { D12 } \\
\text { Utirik } \\
\text { Seamount }\end{array}$ & $11 \cdot 01.2$ & $170 \cdot 10.6$ & $1676-2000$ & $\begin{array}{l}\text { Ferromanganese oxide crust } \\
\text { without substratum }\end{array}$ \\
\hline $\begin{array}{c}\text { D13 } \\
\text { Utirik } \\
\text { Seamount }\end{array}$ & $11 \cdot 00.5$ & $170 \cdot 12.2$ & 2000 & $\begin{array}{l}\text { Ferromanganese oxide crust } \\
\text { without substratum }\end{array}$ \\
\hline $\begin{array}{c}\text { D14 } \\
\text { Utirik } \\
\text { Seamount }\end{array}$ & $11 \cdot 00.6$ & $170 \cdot 13.8$ & 1800 & $\begin{array}{l}\text { Ferromanganese oxide crust } \\
\text { without abstratum }\end{array}$ \\
\hline $\begin{array}{l}\text { D15 } \\
\text { Bikar } \\
\text { Guyot }\end{array}$ & $12 \cdot 11.0$ & $168 \cdot 59.7$ & $1300-1800$ & $\begin{array}{l}\text { phosphatized chalk with minor } \\
\text { amount of well rounded, hishly } \\
\text { vesicular, alkalic basalt clasts }\end{array}$ \\
\hline $\begin{array}{l}\text { D17 } \\
\text { Ratak } \\
\text { Guyot }\end{array}$ & $13 \cdot 54.3$ & $167 \cdot 37.6$ & 1600 & $\begin{array}{l}\text { phosphatized chalk with aparse } \\
\text { pebble-sized clasts of extremely } \\
\text { altered, alkalic basalt }\end{array}$ \\
\hline $\begin{array}{c}\text { D18 } \\
\text { Ratak } \\
\text { Guyot }\end{array}$ & $13 \cdot 54.0$ & $167 \cdot 80.2$ & 1000 & $\begin{array}{l}\text { angular fragments of hawaite } \\
\text { in phosphatized chalk matrix }\end{array}$ \\
\hline $\begin{array}{c}\text { D20 } \\
\text { Trongi } \\
\text { Atoll }\end{array}$ & $14 \cdot 32.6$ & $160 \cdot 0.2$ & $1700-2000$ & $\begin{array}{l}\text { poorly indurated limestone coqui- } \\
\text { na of fore-reef alope deposit }\end{array}$ \\
\hline
\end{tabular}


Table 2: Purographic Data for Voleanic Rock from the Marohall Llanda (mineral abundance baced on vioul enimated)

\begin{tabular}{|c|c|c|c|c|c|c|c|c|c|c|}
\hline $\begin{array}{l}\text { Semple } \\
\text { No. }\end{array}$ & $\begin{array}{l}\text { Rock } \\
\text { Type }\end{array}$ & Mineral Phene & कृgets & Sise & Mineral Grour & dmase & ine & $\begin{array}{c}\text { Vesicles } \\
\text { \% }\end{array}$ & Texture & Remarks \\
\hline D1-1 & TABH & & & & $\begin{array}{l}\text { Plagionlace } \\
\text { Clinopyroxene } \\
\text { Fe-Ti oxide } \\
\text { Olivine } \\
\text { Palogonite }\end{array}$ & $\begin{array}{l}80 \\
18 \\
18 \\
10 \\
10\end{array}$ & $\begin{array}{l}<1 \mathrm{~mm} \\
<0.8 \mathrm{~mm} \\
<0.2 \mathrm{~mm} \\
<0.8 \mathrm{~mm}\end{array}$ & $<1$ & byolopilitic & $\begin{array}{l}\text { broken pillow breocis } \\
\text { with polosonite rind } \\
\text { olivine reploced by } \\
\text { iddinguive, abow for flow } \\
\text { alignment }\end{array}$ \\
\hline D1-7 & TABH & & & & $\begin{array}{l}\text { Plagioclace } \\
\text { Clinopyroxene } \\
\text { Olivine } \\
\text { Fo-Ti oxide } \\
\text { Techylite }\end{array}$ & $\begin{array}{c}88 \\
18 \\
10 \\
12 \\
8\end{array}$ & $\begin{array}{l}<1 \mathrm{~mm} \\
<0.0 \mathrm{~mm} \\
<0.8 \mathrm{~mm} \\
<0.2 \mathrm{~mm}\end{array}$ & $\sim 2$ & intersranular & $\begin{array}{l}\text { tochylitic groundmaes } \\
\text { no glony rind, } \\
\text { olivine replaced by } \\
\text { iddingeice }\end{array}$ \\
\hline D3-1 & TABH & & & & $\begin{array}{l}\text { Plagiocluce } \\
\text { Olivine } \\
\text { Clinopy roxene } \\
\text { Fo-Ti oxide }\end{array}$ & $\begin{array}{l}60 \\
18 \\
10 \\
8\end{array}$ & $\begin{array}{l}<1 \mathrm{~mm} \\
<0.0 \mathrm{~mm} \\
<0.6 \mathrm{~mm} \\
<0.1 \mathrm{~mm}\end{array}$ & 0 & aub-erachytic & $\begin{array}{l}\text { mub-rounded cobble } \\
\text { wachylitic groundmace } \\
\text { no slace rind, } \\
\text { olivine rimmed with } \\
\text { iddingaite, replaced } \\
\text { by smectite clay }\end{array}$ \\
\hline D4-2 & TABH & $\begin{array}{l}\text { Plagioclace } \\
\text { (rounded) } \\
\text { Clinopyroxene } \\
\text { (rounded) }\end{array}$ & $\begin{array}{l}10 \\
<1\end{array}$ & $\begin{array}{l}\sim 2 \mathrm{~mm} \\
0.0 \mathrm{~mm}\end{array}$ & $\begin{array}{l}\text { Plegioclace } \\
\text { Fe-Ti oxide } \\
\text { Olivine } \\
\text { Tacholite }\end{array}$ & $\begin{array}{c}08 \\
10 \\
0 \\
10\end{array}$ & $\begin{array}{l}<1 \mathrm{~mm} \\
<0.4 \mathrm{~mm} \\
<0.2 \mathrm{~mm}\end{array}$ & $\sim 10$ & $\begin{array}{l}\text { wab-irachytic } \\
\text { in } \\
\text { incergranular }\end{array}$ & $\begin{array}{l}\text { phenoergats rounded } \\
\text { and soned, olivine } \\
\text { replaced by smectite } \\
\text { and iddinguite, eloya } \\
\text { seolites and phoophace } \\
\text { line revicles }\end{array}$ \\
\hline D4-3 & TABH & $\begin{array}{l}\text { Plagioclase } \\
\text { (reworbed) }\end{array}$ & $<1$ & $8 \mathrm{~mm}$ & $\begin{array}{l}\text { Plagiocluse } \\
\text { Olivine } \\
\text { Olinopyroxene } \\
\text { Pe-Ti oxide } \\
\text { Tachylite }\end{array}$ & $\begin{array}{c}62 \\
12 \\
8 \\
10 \\
10\end{array}$ & $\begin{array}{l}<1 \mathrm{~mm} \\
<0.8 \mathrm{~mm} \\
<0.1 \mathrm{~mm} \\
<0.2 \mathrm{~mm}\end{array}$ & $<1$ & trechytic & $\begin{array}{l}\text { pillow breccis } \\
\text { oinilar to D1-1 but } \\
\text { has leos stans } \\
\text { and more tachylite } \\
\text { in sroundman,olivine } \\
\text { replaced by amectite } \\
\text { and iddingeite }\end{array}$ \\
\hline D6-1 & $\mathbf{H}$ & $\begin{array}{l}\text { Plagioclane } \\
\text { Fo-Ti oxide }\end{array}$ & $<8$ & $\begin{array}{l}0.4 \mathrm{~mm} \\
<0.2 \mathrm{~mm}\end{array}$ & $\begin{array}{l}\text { Plezioclase } \\
\text { Clinopy roxene } \\
\text { Pe-Ti oxides } \\
\text { Chlorite? }\end{array}$ & $\begin{array}{l}16 \\
10 \\
18 \\
8\end{array}$ & $\begin{array}{l}<0.1 \mathrm{~mm} \\
<10 \mu \\
<10 \mu\end{array}$ & $<1$ & trachytic & $\begin{array}{l}\text { Ti-magnetite is } \\
\text { oxidized,chlorite } \\
\text { may be replacing } \\
\text { biotite, cakite and } \\
\text { clay in vesicles }\end{array}$ \\
\hline Do-10 & $\mathrm{AOB}$ & $\begin{array}{l}\text { Plagioclage } \\
\text { (rounded) } \\
\text { Clinopyroxene } \\
\text { (rounded) }\end{array}$ & $\begin{array}{l}<1 \\
<1\end{array}$ & $\begin{array}{l}\sim 2 \mathrm{~mm} \\
\sim 8 \mathrm{~mm}\end{array}$ & $\begin{array}{l}\text { Plazioclase } \\
\text { Olinopyroxene } \\
\text { Olivine } \\
\text { Pe-Ti oxides } \\
\text { Techylite }\end{array}$ & $\begin{array}{l}08 \\
18 \\
10 \\
2 \\
8\end{array}$ & $\begin{array}{l}<0.8 \mathrm{~mm} \\
<0.8 \mathrm{~mm} \\
<0.2 \mathrm{~mm} \\
<0.1 \mathrm{~mm}\end{array}$ & 0 & trachytic & $\begin{array}{l}\text { olivine replaced } \\
\text { by iddingoite and } \\
\text { onectite, phenocryats } \\
\text { are slo merophric } \\
\text { and rounded }\end{array}$ \\
\hline $\begin{array}{l}\text { DQ-17 } \\
\text { Do-18 }\end{array}$ & AOB & $\begin{array}{l}\text { Olivine } \\
\text { cubedrol } \\
\text { Clinopyroxene } \\
\text { (rounded) } \\
\text { Plagioclace }\end{array}$ & $\begin{array}{l}<0 \\
<1 \\
<1\end{array}$ & $\begin{array}{l}<1 \mathrm{~mm} \\
\sim 2 \mathrm{~mm} \\
\sim 2 \mathrm{~mm}\end{array}$ & $\begin{array}{l}\text { Plagioclace } \\
\text { Clinopyroxene } \\
\text { Olivine } \\
\text { Fo-Ti oxide }\end{array}$ & $\begin{array}{c}80 \\
20 \\
0 \\
18\end{array}$ & $\begin{array}{l}<1 \mathrm{~mm} \\
<0.8 \mathrm{~mm} \\
<0.8 \mathrm{~mm} \\
<0.2 \mathrm{~mm}\end{array}$ & 0 & $\begin{array}{l}\text { intergranular } \\
\text { to } \\
\text { inceraersal }\end{array}$ & $\begin{array}{l}\text { olivine repluced } \\
\text { by omectite,no } \\
\text { iddingtize rim, }\end{array}$ \\
\hline Do-24 & TABH & $\begin{array}{l}\text { Plagioclase } \\
\text { (euhedral) }\end{array}$ & $<\mathbf{1}$ & $2 m m$ & $\begin{array}{l}\text { Plazioclace } \\
\text { Olinopyroxene } \\
\text { Olivine } \\
\text { Fo-Ti oxide } \\
\text { Tachylite }\end{array}$ & $\begin{array}{c}60 \\
10 \\
8 \\
18 \\
10\end{array}$ & $\begin{array}{l}<0.8 \mathrm{~mm} \\
<0.2 \mathrm{~mm} \\
<0.1 \mathrm{~mm} \\
<0.1 \mathrm{~mm}\end{array}$ & 0 & trachytic & $\begin{array}{l}\text { iron oxides } \\
\text { and ometite fill } \\
\text { froctures }\end{array}$ \\
\hline D15-5 & $\mathrm{AOB}$ & $\begin{array}{l}\text { Olivine } \\
\text { (euhedral) } \\
\text { Pyroxene } \\
\text { (euhedral) }\end{array}$ & 25 & $<8 \mathrm{~mm}$ & $\begin{array}{l}\text { Cinopyroxene } \\
\text { Plagioclase? } \\
\text { Olivine? } \\
\text { Opsques } \\
\text { Olayı }\end{array}$ & & & 40 & interaertal & $\begin{array}{l}\text { extremely altered } \\
\text { diffused with iron } \\
\text { oxides, and osponite } \\
\text { reaicles lined with } \\
\text { opponite and carbonate } \\
\text { phosphate }\end{array}$ \\
\hline $\begin{array}{l}\text { D18-1 } \\
\text { D18-8 } \\
\text { D18-8 }\end{array}$ & $\mathbf{H}$ & & & & $\begin{array}{l}\text { Plagioclase } \\
\text { Fe-Ti oxide } \\
\text { Clinopyroxene } \\
\text { Tachylite }\end{array}$ & $\begin{array}{c}70 \\
18 \\
8 \\
12\end{array}$ & $\underset{\substack{<0.01 m m \\
<100 \mu}}{<5 \mu}$ & 10 & trachyrtic & $\begin{array}{l}\text { Iron oxide otsins } \\
\text { olons froctures, } \\
\text { ruge filled with } \\
\text { seolices,poleces of } \\
\text { brow nish chlorice? } \\
\text { opaques oxidised }\end{array}$ \\
\hline
\end{tabular}


Table 3i Major Element Analyses of Voleanic Rocks from the Marshall Islands

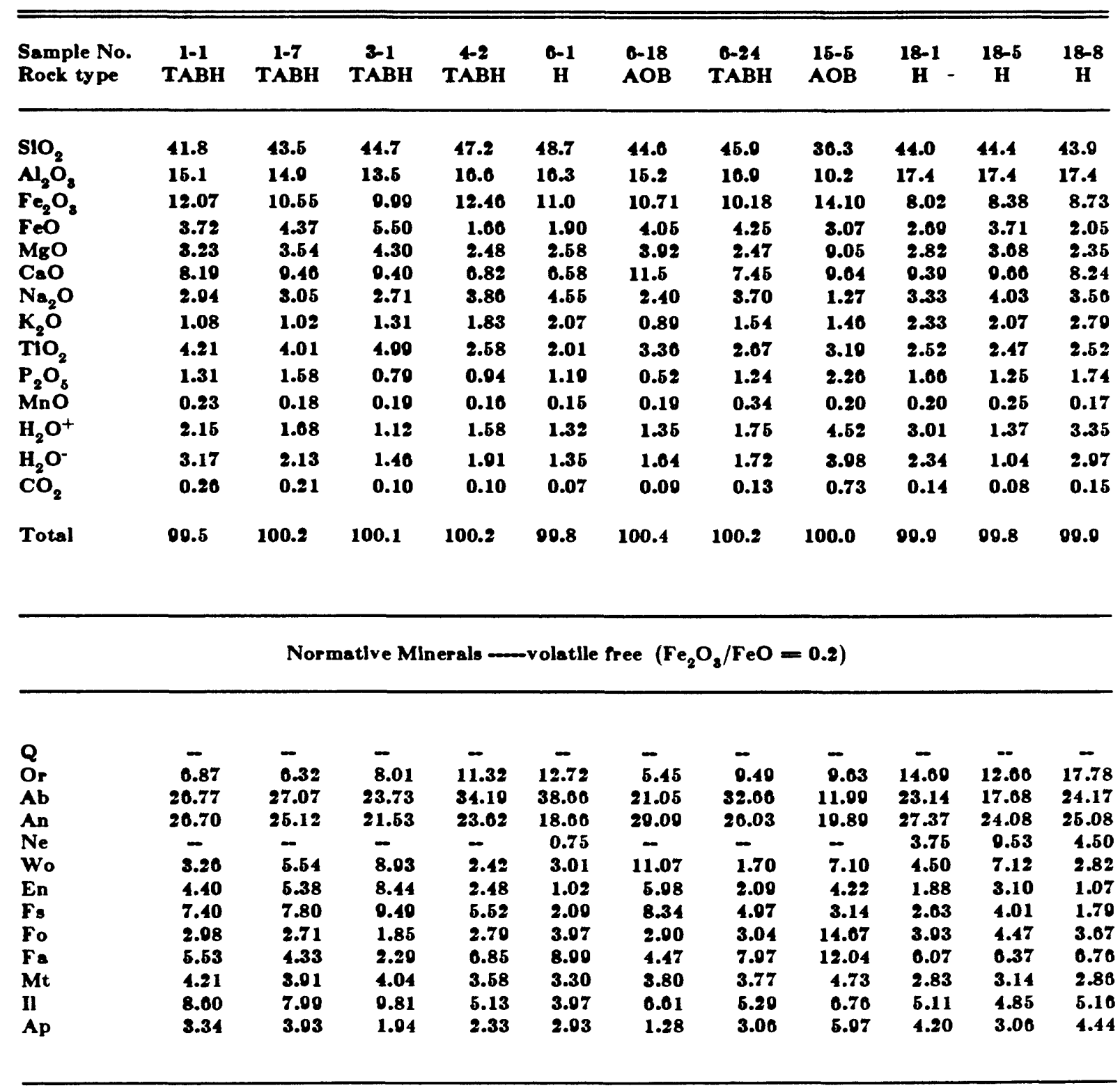

$A O B=$ alkall ollvine basalt

TABH = transitional between alkallc basalt and hawallte

H= hawallte 
Table 4. Trace Element Abundances (ppm) In Volcanic Rocks from the Marshall Islands

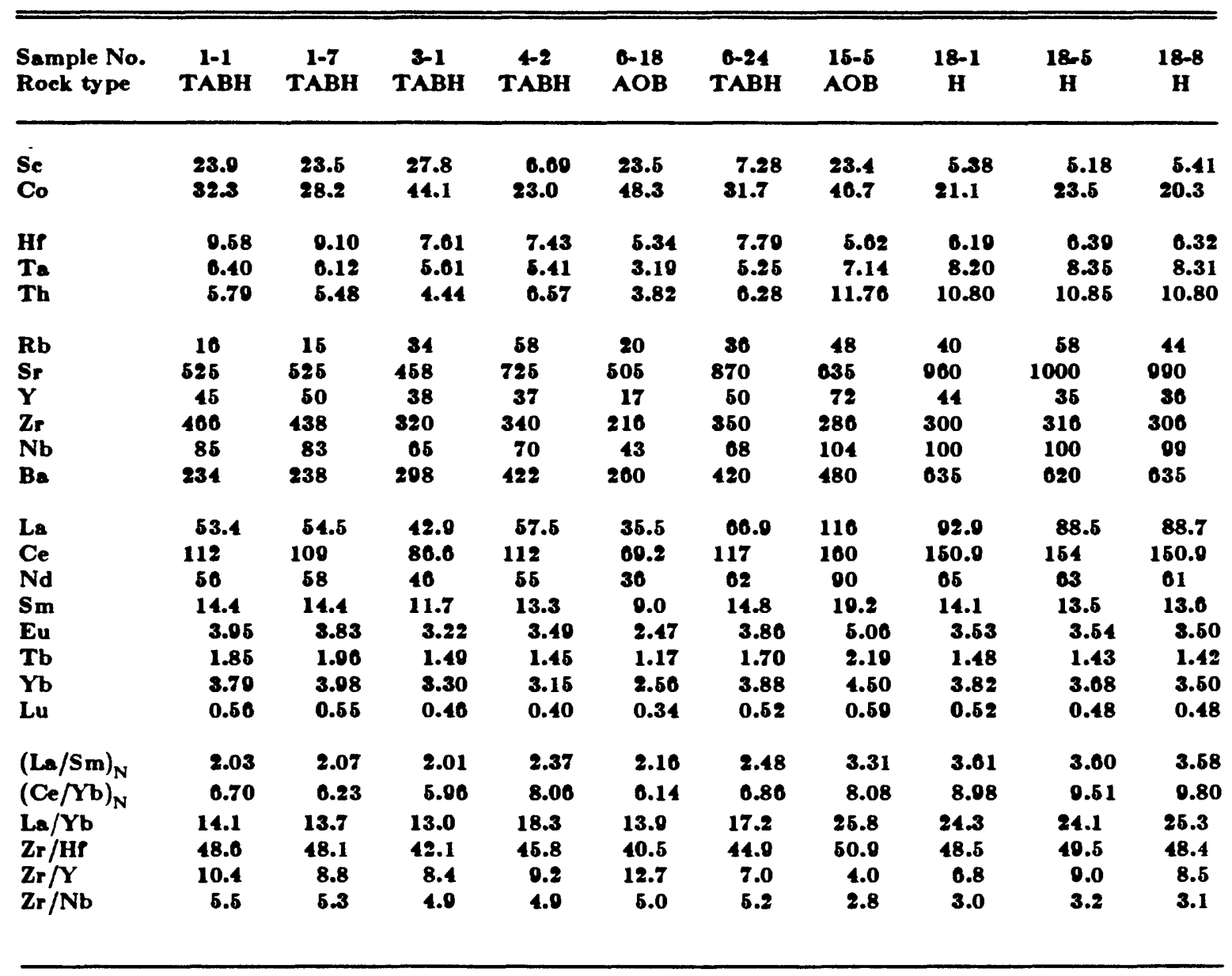

$A O B=$ alkall ollvine basalt

TABH = transitional between alkalic basalt and hawallte

$H=$ hawallte 
Table 5: Plagloclase Analyses

\begin{tabular}{|c|c|c|c|c|c|c|c|c|c|}
\hline Sample No. & $\begin{array}{r}\text { D1-1 } \\
\text { Ime }\end{array}$ & $\begin{array}{c}\text { D1-1 } \\
2 R\end{array}$ & $\begin{array}{l}\text { D1-1 } \\
2 C\end{array}$ & $\begin{array}{r}\text { D1-1 } \\
8 \mathrm{me}\end{array}$ & $\begin{array}{r}\text { D1-1 } \\
\text { Ime }\end{array}$ & $\begin{array}{c}\text { D1-1 } \\
\text { 5R }\end{array}$ & $\begin{array}{r}\text { D1-1 } \\
\text { 5C }\end{array}$ & $\begin{array}{c}\text { D1-1 } \\
\text { Ome }\end{array}$ & $\begin{array}{c}\text { D1-1 } \\
7 \mathrm{me}\end{array}$ \\
\hline $\mathrm{SIO}_{2}$ & 54.2 & 54.5 & 54.0 & 54.8 & 55.3 & 54.7 & 56.2 & 54.0 & 55.4 \\
\hline $\mathrm{Al}_{2} \mathrm{O}_{3}$ & 28.1 & 27.6 & 27.0 & 27.1 & 20.0 & 27.3 & 27.0 & 28.4 & 27.3 \\
\hline $\begin{array}{l}\mathrm{FeO} \\
\mathrm{MgO}\end{array}$ & $\begin{array}{l}0.70 \\
0.13\end{array}$ & $\begin{array}{l}0.70 \\
0.12\end{array}$ & $\begin{array}{l}0.65 \\
0.11\end{array}$ & $\begin{array}{l}0.76 \\
0.15\end{array}$ & $\begin{array}{l}0.83 \\
0.14\end{array}$ & $\begin{array}{l}0.08 \\
0.13\end{array}$ & $\begin{array}{l}0.62 \\
0.10\end{array}$ & $\begin{array}{l}0.71 \\
0.13\end{array}$ & $\begin{array}{l}0.67 \\
0.12\end{array}$ \\
\hline $\begin{array}{l}\mathrm{CaO} \\
\mathrm{K}_{2} \mathrm{O}\end{array}$ & $\begin{array}{c}10.0 \\
0.30\end{array}$ & $\begin{array}{c}10.6 \\
0.32\end{array}$ & $\begin{array}{c}10.6 \\
0.37\end{array}$ & $\begin{array}{c}10.5 \\
0.38\end{array}$ & $\begin{array}{l}0.10 \\
0.58\end{array}$ & $\begin{array}{c}11.0 \\
0.30\end{array}$ & $\begin{array}{l}9.80 \\
0.41\end{array}$ & $\begin{array}{c}11.5 \\
0.27\end{array}$ & $\begin{array}{c}10.5 \\
0.32\end{array}$ \\
\hline $\mathrm{Na}_{2} \mathrm{O}$ & 5.03 & 5.24 & 5.30 & 5.22 & 5.74 & 5.05 & 5.63 & 4.76 & 5.21 \\
\hline SrO & 0.25 & 0.25 & 0.20 & 0.21 & 0.10 & 0.22 & 0.20 & 0.20 & 0.22 \\
\hline Total & 00.5 & 00.2 & 00.4 & 00.2 & 97.0 & 00.4 & 100.0 & 100.0 & 00.8 \\
\hline An & 63.5 & -51.7 & 51.4 & 51.5 & 15.1 & 63.7 & 17.8 & 66.1 & 51.7 \\
\hline $\mathbf{A} \mathbf{b}$ & 14.8 & 10.4 & 40.5 & 10.3 & 51.5 & 14.5 & 40.7 & 12.3 & 46.5 \\
\hline Or & 1.7 & 1.8 & 2.1 & 2.2 & 3.5 & 1.7 & 2.4 & 1.6 & 1.8 \\
\hline
\end{tabular}

\begin{tabular}{cccccccccc}
\hline Sample No. & D3-1 & D3-1 & D3-1 & D3-1 & D3-1 & D3-1 & D4-2 & D4-2 & D4-2 \\
1R & $1 C$ & $2 R$ & $2 C$ & $3 m e$ & ime & 1me & 2me & $3 m e$ \\
\hline
\end{tabular}

\begin{tabular}{|c|c|c|c|c|c|c|c|c|c|}
\hline $\mathrm{SiO}_{2}$ & 53.1 & $\begin{array}{l}53.7 \\
28.8\end{array}$ & 53.0 & $\begin{array}{l}53.6 \\
28.8\end{array}$ & $\begin{array}{l}53.0 \\
28.0\end{array}$ & $\begin{array}{l}53.4 \\
28.7\end{array}$ & $\begin{array}{l}54.7 \\
28.8\end{array}$ & 54.0 & 55.1 \\
\hline $\begin{array}{l}\mathrm{Al}_{2} \mathrm{O}_{3} \\
\mathrm{FeO} \\
\mathrm{MgO}\end{array}$ & $\begin{array}{c}28.0 \\
0.77 \\
0.14\end{array}$ & $\begin{array}{c}28.8 \\
0.77 \\
0.13\end{array}$ & $\begin{array}{c}28.5 \\
0.71 \\
0.13\end{array}$ & $\begin{array}{r}28.8 \\
0.66 \\
0.15\end{array}$ & $\begin{array}{c}28.0 \\
1.07 \\
0.30\end{array}$ & $\begin{array}{l}28.7 \\
0.81 \\
0.18\end{array}$ & $\begin{array}{c}28.8 \\
0.38 \\
0.08\end{array}$ & $\begin{array}{c}28.1 \\
0.16 \\
0.10\end{array}$ & $\begin{array}{c}28.3 \\
0.41 \\
0.07\end{array}$ \\
\hline $\begin{array}{l}\mathrm{CaO} \\
\mathrm{K}_{2} \mathrm{O}\end{array}$ & $\begin{array}{c}11.9 \\
0.29\end{array}$ & $\begin{array}{c}11.7 \\
0.31\end{array}$ & $\begin{array}{c}12.0 \\
0.20\end{array}$ & $\begin{array}{c}11.0 \\
0.31\end{array}$ & $\begin{array}{c}11.0 \\
0.45\end{array}$ & $\begin{array}{c}11.7 \\
0.31\end{array}$ & $\begin{array}{c}10.0 \\
0.27\end{array}$ & $\begin{array}{c}10.5 \\
0.38\end{array}$ & $\begin{array}{c}10.9 \\
0.25\end{array}$ \\
\hline $\mathrm{Na}_{2} \mathrm{O}$ & 4.63 & 4.66 & 4.40 & 4.66 & 4.54 & 4.08 & 5.30 & 5.26 & 5.34 \\
\hline SrO & 0.22 & 0.24 & 0.17 & 0.10 & 0.23 & 0.20 & 0.31 & 0.33 & 0.27 \\
\hline Total & 00.7 & 100.3 & 09.8 & 80.0 & 100.1 & 80.0 & 100.7 & 100.3 & 100.7 \\
\hline An & 58.2 & 57.0 & 58.5 & 57.0 & 57.0 & 56.9 & 52.5 & 51.4 & 52.2 \\
\hline $\mathbf{A b}$ & 10.0 & 11.2 & 30.8 & 11.2 & 10.1 & 11.3 & 16.0 & 40.4 & 16.3 \\
\hline n- & 1.7 & 1.8 & 1.7 & 1.8 & 2.6 & 1.8 & 1.5 & 2.2 & 1.5 \\
\hline
\end{tabular}

\footnotetext{
mex= core of small crystal

R= rim of larger crystal

$C=$ core of larger crystal
} 
Table 5: continued

\begin{tabular}{|c|c|c|c|c|c|c|c|c|c|c|}
\hline Sample No. & $\begin{array}{l}\text { D4-2 } \\
\text { Ime }\end{array}$ & $\begin{array}{l}\text { Do-1 } \\
\text { Ime }\end{array}$ & $\begin{array}{l}\text { Do-1 } \\
2 \mathrm{me}\end{array}$ & $\begin{array}{l}\text { D6-1 } \\
\text { 3me }\end{array}$ & $\begin{array}{l}\text { D6-1 } \\
\text { Ime }\end{array}$ & $\begin{array}{c}\text { DQ-17 } \\
\text { IR }\end{array}$ & $\begin{array}{c}D 0-17 \\
1 C\end{array}$ & $\begin{array}{c}\text { D6-17 } \\
2 \mathrm{me}\end{array}$ & $\begin{array}{c}\text { DQ-17 } \\
\text { 3mé }\end{array}$ & $\begin{array}{c}\text { De-18 } \\
\text { lme }\end{array}$ \\
\hline $\mathrm{SIO}_{2}$ & 54.8 & 57.0 & 50.4 & 55.0 & 56.0 & 16.8 & 47.0 & 51.2 & 51.0 & 51.1 \\
\hline $\mathbf{N}_{2} \dot{O}_{3}$ & 28.4 & 26.0 & 26.8 & 27.7 & 27.3 & 33.4 & 32.4 & 80.4 & 28.0 & 80.2 \\
\hline $\begin{array}{l}\text { FeO } \\
\mathrm{MgO}\end{array}$ & $\begin{array}{l}0.51 \\
0.05\end{array}$ & $\begin{array}{l}0.40 \\
0.05\end{array}$ & $\begin{array}{l}0.54 \\
0.05\end{array}$ & $\begin{array}{l}0.55 \\
0.03\end{array}$ & $\begin{array}{l}0.07 \\
0.03\end{array}$ & $\begin{array}{l}0.64 \\
0.12\end{array}$ & $\begin{array}{l}0.57 \\
0.13\end{array}$ & $\begin{array}{l}0.75 \\
0.13\end{array}$ & $\begin{array}{l}1.17 \\
0.33\end{array}$ & $\begin{array}{l}0.03 \\
0.14\end{array}$ \\
\hline $\begin{array}{l}\mathrm{CaO} \\
\mathrm{K}_{2} \mathrm{O}\end{array}$ & $\begin{array}{c}10.8 \\
0.20\end{array}$ & $\begin{array}{l}8.43 \\
0.51\end{array}$ & $\begin{array}{l}0.55 \\
0.85\end{array}$ & $\begin{array}{c}10.1 \\
0.38\end{array}$ & $\begin{array}{l}0.02 \\
0.51\end{array}$ & $\begin{array}{c}17.1 \\
0.07\end{array}$ & $\begin{array}{c}10.5 \\
0.07\end{array}$ & $\begin{array}{c}13.0 \\
0.16\end{array}$ & $\begin{array}{c}13.2 \\
0.20\end{array}$ & $\begin{array}{c}13.4 \\
0.18\end{array}$ \\
\hline $\mathrm{Na}_{2} \mathrm{O}$ & 5.25 & 0.43 & 5.54 & 5.61 & 5.81 & 1.80 & 2.08 & 8.73 & 4.00 & 3.77 \\
\hline SrO & $\mathbf{0 . 3 0}$ & 0.35 & 0.31 & 0.45 & 0.35 & 0.22 & 0.21 & 0.21 & 0.18 & 0.20 \\
\hline Total & 100.4 & 100.0 & 100.1 & 100.6 & 100.2 & 100.2 & 00.0 & 100.2 & 00.0 & 00.0 \\
\hline An & 52.3 & 10.7 & 16.3 & 48.7 & 16.3 & 83.7 & 81.1 & 66.3 & 03.5 & 05.6 \\
\hline $\mathbf{A b}$ & 16.0 & 50.3 & 18.7 & 10.0 & 50.7 & 15.0 & 18.5 & 32.8 & 34.8 & 33.4 \\
\hline Or & 1.7 & 2.0 & 4.0 & 2.2 & 3.0 & 0.4 & 0.4 & 0.0 & 1.7 & 1.0 \\
\hline
\end{tabular}

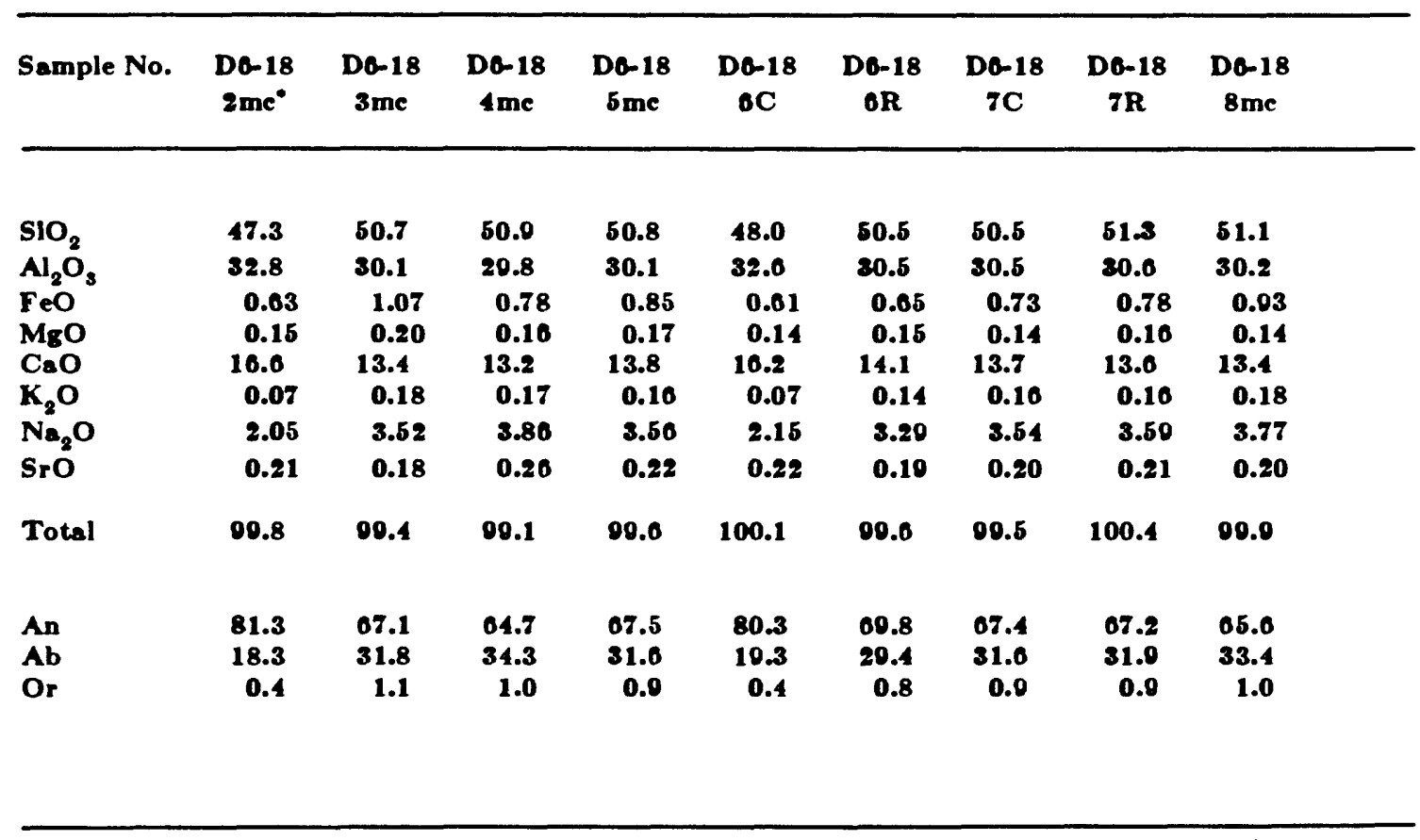

- included in ellnopyroxene phenocryst 
Table 6: Clinopy roxene Anabyes

\begin{tabular}{|c|c|c|c|c|c|c|c|c|c|c|c|}
\hline Sample No. & $\begin{array}{c}\text { D1-1 } \\
\text { IR }\end{array}$ & $\begin{array}{c}\text { D1-1 } \\
1 \mathrm{C}\end{array}$ & $\begin{array}{c}\text { D1-1 } \\
2 R\end{array}$ & $\begin{array}{c}\text { D1-1 } \\
2 \mathrm{C}\end{array}$ & $\begin{array}{c}\text { D1-1 } \\
\text { 8R }\end{array}$ & $\begin{array}{l}\text { D1-1 } \\
\text { 8C }\end{array}$ & $\begin{array}{c}\text { D1-1 } \\
\text { \&R }\end{array}$ & $\begin{array}{c}\text { D1-1 } \\
\text { IC }\end{array}$ & $\underset{8 R}{\text { D1-1 }}$ & $\underset{5 C}{D 1-1}$ & $\begin{array}{l}\text { D1-1 } \\
\text { Ome }\end{array}$ \\
\hline & & & & & & & & & & - & \\
\hline $\mathrm{SiO}_{2}$ & 18.7 & 81.3 & 16.0 & 47.5 & 49.5 & 40.5 & 81.8 & 17.8 & 40.6 & 81.0 & 48.9 \\
\hline $\mathrm{TiO}_{2}$ & 2.15 & 1.22 & 8.17 & 2.75 & 2.16 & 1.80 & 1.22 & 2.75 & 1.97 & 1.14 & 2.32 \\
\hline $\mathrm{Al}_{2} \mathrm{O}_{8}$ & 4.32 & 2.33 & 5.52 & 5.20 & 4.05 & 8.98 & 1.97 & 5.50 & 8.43 & 1.80 & 4.00 \\
\hline $\begin{array}{l}\mathrm{FeO} \\
\mathrm{Cr}_{2} \mathrm{O}_{8}\end{array}$ & $\begin{array}{l}9.60 \\
0.00\end{array}$ & $\begin{array}{c}10.6 \\
0.00\end{array}$ & $\begin{array}{c}10.6 \\
0.01\end{array}$ & $\begin{array}{l}9.77 \\
0.00\end{array}$ & $\begin{array}{l}9.03 \\
0.00\end{array}$ & $\begin{array}{c}10.8 \\
0.00\end{array}$ & $\begin{array}{l}9.02 \\
0.00\end{array}$ & $\begin{array}{c}10.1 \\
0.01\end{array}$ & $\begin{array}{l}9.88 \\
0.00\end{array}$ & $\begin{array}{c}10.8 \\
0.01\end{array}$ & $\begin{array}{l}9.40 \\
0.01\end{array}$ \\
\hline Mno & 0.21 & 0.32 & 0.24 & 0.21 & 0.24 & 0.28 & 0.20 & 0.25 & 0.20 & 0.34 & 0.23 \\
\hline MgO & 13.0 & 15.0 & 12.3 & 12.8 & 13.6 & 18.3 & 18.2 & 12.8 & 13.9 & 15.1 & 13.1 \\
\hline $\begin{array}{l}\mathrm{CaO} \\
\mathrm{Na}_{2} \mathrm{O}\end{array}$ & $\begin{array}{c}20.7 \\
0.46\end{array}$ & $\begin{array}{c}18.0 \\
0.81\end{array}$ & $\begin{array}{c}20.4 \\
0.54\end{array}$ & $\begin{array}{c}20.0 \\
0.49\end{array}$ & $\begin{array}{c}20.7 \\
0.44\end{array}$ & $\begin{array}{c}19.8 \\
0.80\end{array}$ & $\begin{array}{c}20.4 \\
0.36\end{array}$ & $\begin{array}{c}19.8 \\
0.54\end{array}$ & $\begin{array}{c}20.3 \\
0.38\end{array}$ & $\begin{array}{c}18.6 \\
0.30\end{array}$ & $\begin{array}{c}20.5 \\
0.63\end{array}$ \\
\hline Total & 90.8 & 100.0 & 09.3 & 00.4 & 100.2 & 100.0 & 100.1 & 90.1 & 00.0 & 00.2 & 90.6 \\
\hline
\end{tabular}

Cations based on aix oxy gens

\begin{tabular}{|c|c|c|c|c|c|c|c|c|c|c|c|}
\hline $\mathbf{S i}$ & 1.822 & 1.016 & 1.747 & 1.772 & 1.853 & 1.860 & 1.021 & 1.758 & 1.844 & 1.887 & 1.821 \\
\hline $\mathbf{T} \mathbf{i}$ & 0.061 & 0.034 & 0.080 & 0.077 & 0.061 & 0.053 & 0.034 & 0.077 & 0.055 & 0.032 & 0.085 \\
\hline $\begin{array}{l}\text { Al } \\
\text { Fe }\end{array}$ & $\begin{array}{l}0.100 \\
0.302\end{array}$ & $\begin{array}{l}0.103 \\
0.331\end{array}$ & $\begin{array}{l}0.244 \\
0.333\end{array}$ & $\begin{array}{l}0.233 \\
0.305\end{array}$ & $\begin{array}{l}0.170 \\
0.301\end{array}$ & $\begin{array}{l}0.176 \\
0.341\end{array}$ & $\begin{array}{l}0.086 \\
0.280\end{array}$ & $\begin{array}{l}0.244 \\
0.814\end{array}$ & $\begin{array}{l}0.151 \\
0.208\end{array}$ & $\begin{array}{l}0.082 \\
0.334\end{array}$ & $\begin{array}{l}0.202 \\
0.206\end{array}$ \\
\hline $\begin{array}{l}\mathbf{C r}_{\mathbf{r}} \\
\mathbf{M n}\end{array}$ & $\begin{array}{l}0.000 \\
0.007\end{array}$ & $\begin{array}{l}0.000 \\
0.010\end{array}$ & $\begin{array}{l}0.000 \\
0.008\end{array}$ & $\begin{array}{l}0.000 \\
0.007\end{array}$ & $\begin{array}{l}0.000 \\
0.008\end{array}$ & $\begin{array}{l}0.000 \\
0.000\end{array}$ & $\begin{array}{l}0.000 \\
0.008\end{array}$ & $\begin{array}{l}0.000 \\
0.008\end{array}$ & $\begin{array}{l}0.000 \\
0.008\end{array}$ & $\begin{array}{l}0.000 \\
0.011\end{array}$ & $\begin{array}{l}0.000 \\
0.007\end{array}$ \\
\hline $\mathbf{M g}$ & 0.758 & 0.833 & 0.086 & 0.710 & 0.750 & 0.743 & 0.841 & 0.700 & 0.770 & 0.831 & 0.726 \\
\hline $\begin{array}{l}\mathrm{Ca} \\
\mathrm{Na}\end{array}$ & $\begin{array}{l}0.820 \\
0.033\end{array}$ & $\begin{array}{l}0.750 \\
0.023\end{array}$ & $\begin{array}{l}0.810 \\
0.030\end{array}$ & $\begin{array}{l}0.824 \\
0.036\end{array}$ & $\begin{array}{l}0.830 \\
0.032\end{array}$ & $\begin{array}{l}0.709 \\
0.037\end{array}$ & $\begin{array}{l}0.811 \\
0.026\end{array}$ & $\begin{array}{l}0.702 \\
0.039\end{array}$ & $\begin{array}{l}0.812 \\
0.028\end{array}$ & $\begin{array}{l}0.738 \\
0.021\end{array}$ & $\begin{array}{l}0.817 \\
0.038\end{array}$ \\
\hline
\end{tabular}

Pyroxene components (molar \%)

\begin{tabular}{|c|c|c|c|c|c|c|c|c|c|c|c|}
\hline $\begin{array}{l}\mathrm{Cz}_{\mathbf{2}} \\
\mathbf{M} \mathbf{g}\end{array}$ & $\begin{array}{l}43.0 \\
40.1\end{array}$ & $\begin{array}{l}30.5 \\
43.3\end{array}$ & $\begin{array}{l}14.0 \\
37.3\end{array}$ & $\begin{array}{l}44.8 \\
38.6\end{array}$ & $\begin{array}{l}44.1 \\
30.0\end{array}$ & $\begin{array}{l}42.4 \\
30.5\end{array}$ & $\begin{array}{l}42.0 \\
43.5\end{array}$ & $\begin{array}{l}43.6 \\
30.1\end{array}$ & $\begin{array}{l}43.0 \\
40.7\end{array}$ & $\begin{array}{l}38.8 \\
43.7\end{array}$ & $\begin{array}{l}44.4 \\
30.5\end{array}$ \\
\hline $\mathbf{F e}^{\mathbf{T}}$ & 10.0 & 17.2 & 18.1 & 10.0 & 10.0 & 18.1 & 14.5 & 17.3 & 10.3 & 17.0 & 10.1 \\
\hline
\end{tabular}

me- core of small crystal

R - rim of larger crystal

C - core of larger erystal 
Table 6: continued

\begin{tabular}{|c|c|c|c|c|c|c|c|c|c|c|c|}
\hline Sample No. & $\begin{array}{c}\mathrm{Dz}-1 \\
1 \mathrm{mc}\end{array}$ & $\begin{array}{l}\mathrm{Da-1} \\
2 \mathrm{mc}\end{array}$ & $\begin{array}{l}\text { D2-1 } \\
\text { smc }\end{array}$ & $\begin{array}{c}\text { D2-1 } \\
\text { IR }\end{array}$ & $\begin{array}{c}D 2-1 \\
4 C\end{array}$ & $\begin{array}{c}\text { D3-1 } \\
8 R\end{array}$ & $\begin{array}{c}\mathrm{D}-1 \\
5 \mathrm{C}\end{array}$ & $\begin{array}{c}\mathrm{Dan} 1 \\
\text { Omc }\end{array}$ & $\underset{\text { DR }}{\text { D3-1 }}$ & $\begin{array}{c}\mathrm{Da}-1 \\
7 \mathrm{C}\end{array}$ & $\begin{array}{c}\mathrm{Dz}-1 \\
8 \mathrm{mc}\end{array}$ \\
\hline $\begin{array}{l}\mathrm{SiO}_{2} \\
\mathrm{TiO}_{2} \\
\mathrm{Al}_{2} \mathrm{O}_{8} \\
\mathrm{FeO} \\
\mathrm{Cr}_{2} \mathrm{O}_{8} \\
\mathrm{MnO} \\
\mathrm{MgO} \\
\mathrm{CaO} \\
\mathrm{Na}_{2} \mathrm{O}\end{array}$ & $\begin{array}{c}48.8 \\
8.48 \\
8.00 \\
0.85 \\
0.00 \\
0.10 \\
12.6 \\
20.7 \\
0.40\end{array}$ & $\begin{array}{c}50.8 \\
1.48 \\
2.82 \\
11.2 \\
0.00 \\
0.80 \\
16.7 \\
17.8 \\
0.81\end{array}$ & $\begin{array}{c}48.1 \\
2.40 \\
4.81 \\
0.81 \\
0.00 \\
0.22 \\
18.4 \\
20.3 \\
0.61\end{array}$ & $\begin{array}{c}40.6 \\
8.25 \\
5.40 \\
10.2 \\
0.00 \\
0.21 \\
12.6 \\
20.4 \\
0.51\end{array}$ & $\begin{array}{c}46.0 \\
2.87 \\
6.16 \\
0.81 \\
0.00 \\
0.18 \\
18.8 \\
20.1 \\
0.48\end{array}$ & $\begin{array}{c}40.8 \\
2.16 \\
8.00 \\
0.80 \\
0.00 \\
0.10 \\
12.8 \\
20.0 \\
0.85\end{array}$ & $\begin{array}{c}47.0 \\
2.06 \\
4.05 \\
0.04 \\
0.00 \\
0.18 \\
13.0 \\
20.6 \\
0.51\end{array}$ & $\begin{array}{c}48.1 \\
2.47 \\
4.07 \\
0.73 \\
0.00 \\
0.20 \\
13.2 \\
20.4 \\
0.50\end{array}$ & $\begin{array}{c}47.2 \\
8.04 \\
5.16 \\
10.2 \\
0.00 \\
0.10 \\
12.7 \\
20.6 \\
0.48\end{array}$ & $\begin{array}{c}48.0 \\
8.27 \\
5.53 \\
10.8 \\
0.00 \\
0.20 \\
12.8 \\
20.4 \\
0.81\end{array}$ & $\begin{array}{c}80.0 \\
1.50 \\
2.58 \\
10.0 \\
0.01 \\
0.81 \\
15.5 \\
18.1 \\
0.28\end{array}$ \\
\hline Total & 00.3 & 00.0 & 00.5 & 00.1 & 98.5 & $\infty .0$ & 00.8 & 00.6 & 00.6 & 08.5 & 100.0 \\
\hline \multicolumn{12}{|c|}{ Cations based on six oxy gens } \\
\hline $\begin{array}{l}\text { Si } \\
\text { Ti } \\
\text { Al } \\
\text { Fe } \\
\text { Cr } \\
\text { Mn } \\
\text { Mz } \\
\text { Ca } \\
\text { Na }\end{array}$ & $\begin{array}{l}1.733 \\
0.008 \\
0.251 \\
0.308 \\
0.000 \\
0.006 \\
0.096 \\
0.831 \\
0.036\end{array}$ & $\begin{array}{l}1.882 \\
0.040 \\
0.100 \\
0.345 \\
0.000 \\
0.000 \\
0.802 \\
0.083 \\
0.022\end{array}$ & $\begin{array}{l}1.794 \\
0.009 \\
0.212 \\
0.206 \\
0.000 \\
0.007 \\
0.743 \\
0.811 \\
0.037\end{array}$ & $\begin{array}{l}1.784 \\
0.091 \\
0.241 \\
0.317 \\
0.000 \\
0.007 \\
0.701 \\
0.815 \\
0.087\end{array}$ & $\begin{array}{l}1.722 \\
0.080 \\
0.225 \\
0.803 \\
0.000 \\
0.006 \\
0.784 \\
0.796 \\
0.083\end{array}$ & $\begin{array}{l}1.758 \\
0.089 \\
0.248 \\
0.311 \\
0.000 \\
0.006 \\
0.702 \\
0.840 \\
0.040\end{array}$ & $\begin{array}{l}1.774 \\
0.075 \\
0.217 \\
0.800 \\
0.000 \\
0.006 \\
0.724 \\
0.824 \\
0.037\end{array}$ & $\begin{array}{l}1.708 \\
0.070 \\
0.210 \\
0.304 \\
0.000 \\
0.006 \\
0.736 \\
0.817 \\
0.037\end{array}$ & $\begin{array}{l}1.767 \\
0.086 \\
0.228 \\
0.810 \\
0.000 \\
0.006 \\
0.710 \\
0.826 \\
0.086\end{array}$ & $\begin{array}{l}1.708 \\
0.001 \\
0.242 \\
0.820 \\
0.000 \\
0.006 \\
0.070 \\
0.810 \\
0.087\end{array}$ & $\begin{array}{l}1.002 \\
0.042 \\
0.111 \\
0.841 \\
0.000 \\
0.010 \\
0.862 \\
0.722 \\
0.020\end{array}$ \\
\hline \multicolumn{12}{|c|}{ Pyroxene components (molar \%) } \\
\hline \multirow{2}{*}{$\begin{array}{l}\mathrm{Cz} \\
\mathrm{ME} \\
\mathrm{Fe}^{\mathrm{T}}\end{array}$} & $\begin{array}{l}\mathbf{1 5 . 3} \\
\mathbf{8 7 . 0}\end{array}$ & $\begin{array}{l}36.1 \\
48.6\end{array}$ & $\begin{array}{l}18.6 \\
80.0\end{array}$ & $\begin{array}{l}44.5 \\
38.2\end{array}$ & $\begin{array}{l}43.4 \\
40.0\end{array}$ & $\begin{array}{l}45.8 \\
87.9\end{array}$ & $\begin{array}{l}14.6 \\
30.2\end{array}$ & $\begin{array}{l}44.0 \\
89.6\end{array}$ & $\begin{array}{l}44.5 \\
38.8\end{array}$ & $\begin{array}{l}44.8 \\
87.6\end{array}$ & $\begin{array}{l}37.5 \\
44.8\end{array}$ \\
\hline & 10.8 & 18.8 & 10.5 & 17.8 & 10.5 & 16.8 & 16.2 & 16.4 & 17.2 & 17.7 & 17.7 \\
\hline
\end{tabular}


Table 6: continued

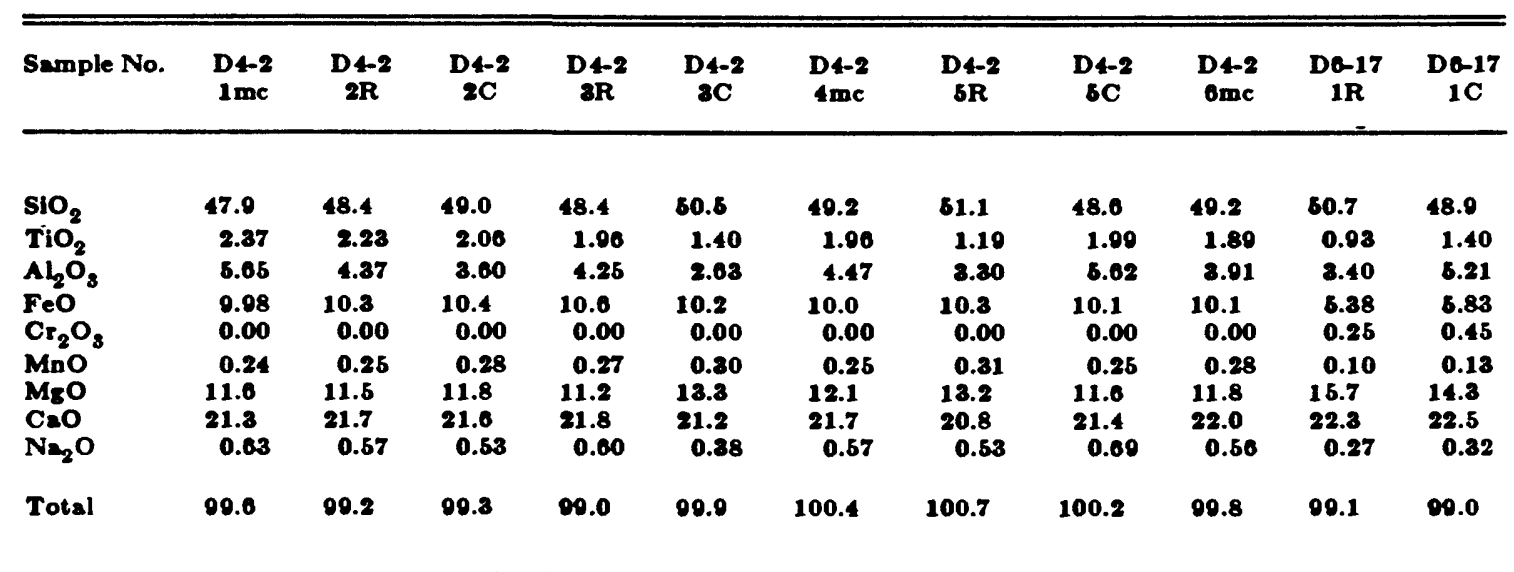

catlons based on six oxy gens

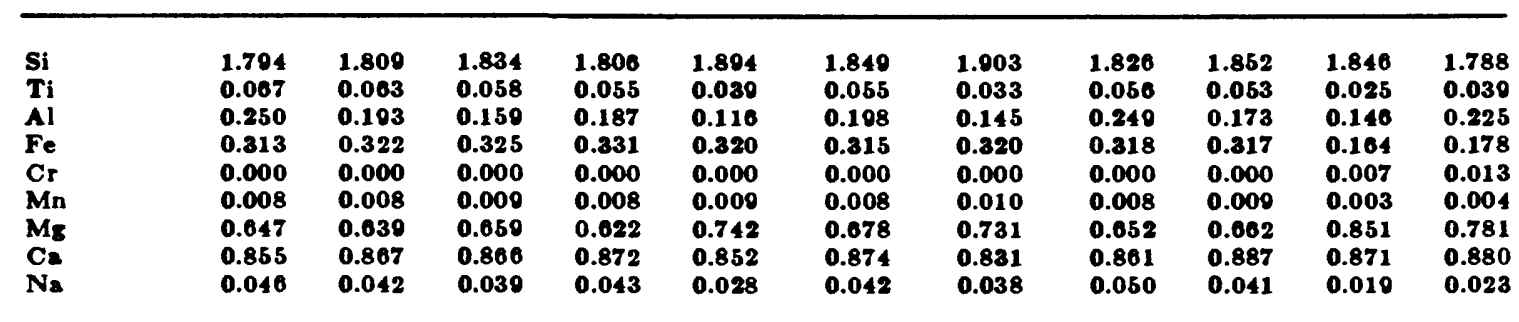

Pyroxene Components (molar \%)

\begin{tabular}{|c|c|c|c|c|c|c|c|c|c|c|c|}
\hline $\begin{array}{l}\mathrm{Cs}_{\mathbf{8}} \\
\mathbf{M}\end{array}$ & $\begin{array}{l}47.1 \\
35.6\end{array}$ & $\begin{array}{l}47.4 \\
85.0\end{array}$ & $\begin{array}{l}40.8 \\
35.6\end{array}$ & $\begin{array}{l}47.8 \\
84.1\end{array}$ & $\begin{array}{l}44.5 \\
38.8\end{array}$ & $\begin{array}{l}40.8 \\
30.3\end{array}$ & $\begin{array}{l}44.2 \\
38.8\end{array}$ & $\begin{array}{l}47.0 \\
35.0\end{array}$ & $\begin{array}{l}47.5 \\
35.5\end{array}$ & $\begin{array}{l}40.2 \\
45.1\end{array}$ & $\begin{array}{l}47.0 \\
42.5\end{array}$ \\
\hline $\mathrm{Fe}^{\mathrm{T}}$ & 17.2 & 17.0 & 17.0 & 18.1 & 10.7 & 16.0 & 17.0 & 17.4 & 17.0 & 8.7 & 9.7 \\
\hline
\end{tabular}


Table 6: continued

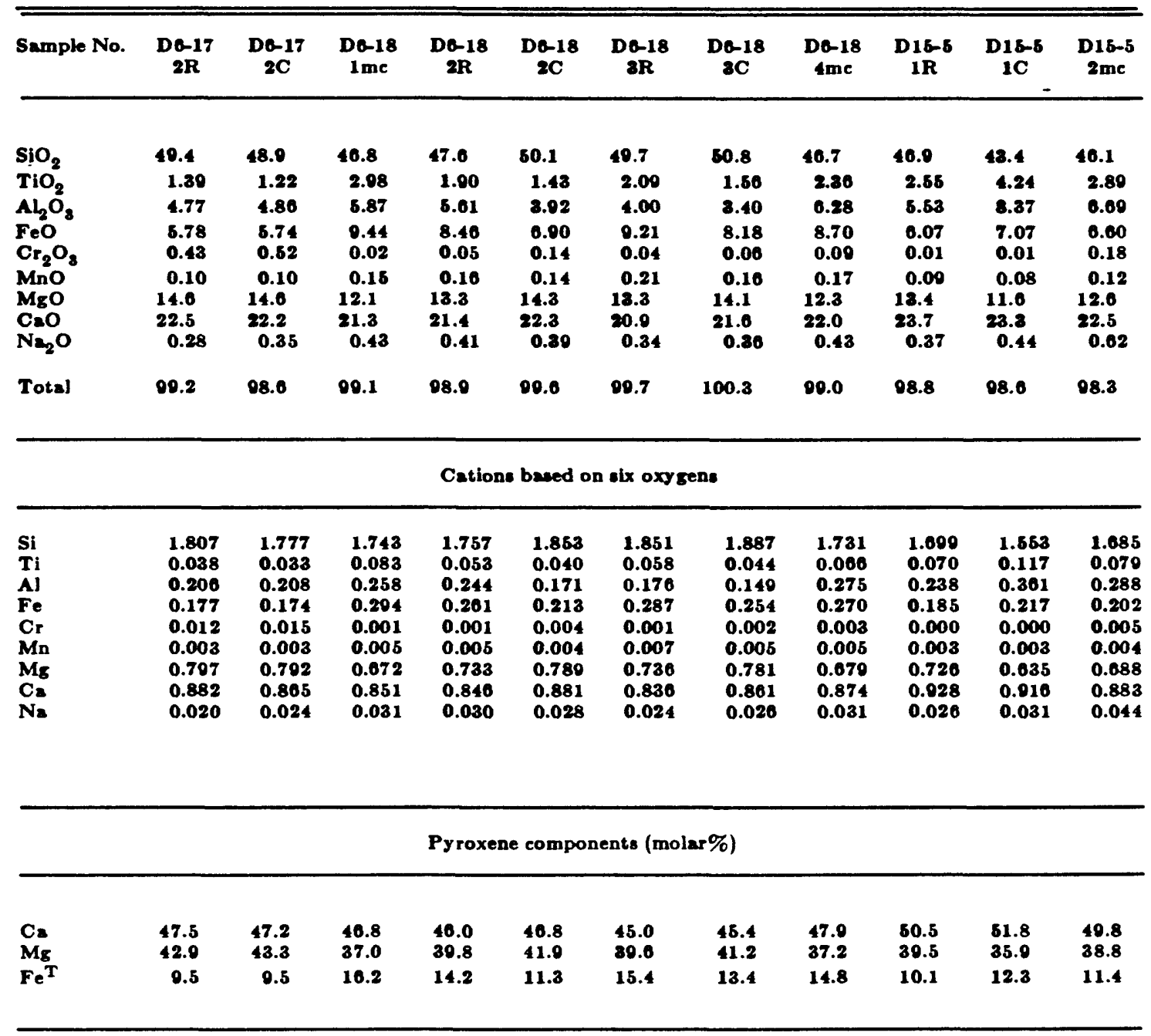


Table 7: Fe-TI Oxide Analyses

\begin{tabular}{|c|c|c|c|c|c|c|c|c|c|}
\hline Sample No. & $\begin{array}{l}\text { D1-1 } \\
\text { I me }\end{array}$ & $\begin{array}{l}\text { D1-1 } \\
2 \mathrm{me}\end{array}$ & $\begin{array}{l}\text { D1-1 } \\
\text { 8me }\end{array}$ & $\begin{array}{l}\text { D3-1 } \\
1 \mathrm{me}\end{array}$ & $\begin{array}{l}\text { D3-1 } \\
2 \mathrm{me}\end{array}$ & $\begin{array}{l}\text { D3-1 } \\
\text { 8me }\end{array}$ & $\begin{array}{l}\text { D3-1 } \\
\text { Ime }\end{array}$ & $\begin{array}{l}\text { D4-2 } \\
\text { IR }\end{array}$ & $\begin{array}{l}D 4-2 \\
1 G\end{array}$ \\
\hline $\begin{array}{l}\mathrm{MgO} \\
\mathrm{N}_{2} \mathrm{O}_{3}\end{array}$ & $\begin{array}{l}4.07 \\
4.42\end{array}$ & $\begin{array}{l}1.25 \\
2.00\end{array}$ & $\begin{array}{l}4.05 \\
4.40\end{array}$ & $\begin{array}{l}4.18 \\
3.40\end{array}$ & $\begin{array}{l}\mathbf{3 . 0 0} \\
8.35\end{array}$ & $\begin{array}{l}1.02 \\
3.00\end{array}$ & $\begin{array}{l}\mathbf{3 . 8 0} \\
\mathbf{3 . 2 2}\end{array}$ & $\begin{array}{l}2.81 \\
8.05\end{array}$ & $\begin{array}{l}3.71 \\
4.04\end{array}$ \\
\hline $\mathrm{SiO}_{2}$ & $\mathbf{8 . 4 8}$ & 0.00 & $\mathbf{8 . 8 4}$ & 0.00 & 0.00 & 0.00 & $\mathbf{0 . 0 0}$ & 0.00 & 0.00 \\
\hline $\begin{array}{l}\mathrm{CaO} \\
\mathrm{TiO}_{2}\end{array}$ & $\begin{array}{l}0.50 \\
21.0\end{array}$ & $\begin{array}{l}0.00 \\
22.2\end{array}$ & $\begin{array}{c}0.04 \\
20.3\end{array}$ & $\begin{array}{c}0.08 \\
23.4\end{array}$ & $\begin{array}{c}0.15 \\
24.4\end{array}$ & $\begin{array}{l}0.20 \\
24.1\end{array}$ & $\begin{array}{c}0.09 \\
24.0\end{array}$ & $\begin{array}{l}0.04 \\
22.7\end{array}$ & $\begin{array}{c}0.03 \\
22.2\end{array}$ \\
\hline $\mathbf{V}_{2} \mathbf{O}_{8}$ & 0.54 & 0.56 & 0.50 & 0.73 & 0.76 & 0.71 & 0.71 & 0.13 & 0.20 \\
\hline $\mathrm{Cr}_{2} \mathrm{O}_{8}$ & 0.01 & 0.03 & 0.02 & 0.06 & 0.05 & 0.05 & 0.07 & 0.01 & 0.00 \\
\hline $\begin{array}{l}\mathrm{MnO} \\
\mathrm{FeO}\end{array}$ & $\begin{array}{c}0.44 \\
01.0\end{array}$ & $\begin{array}{c}0.51 \\
05.0\end{array}$ & $\begin{array}{c}0.43 \\
02.7\end{array}$ & $\begin{array}{c}0.45 \\
06.0\end{array}$ & $\begin{array}{c}0.40 \\
04.8\end{array}$ & $\begin{array}{c}0.46 \\
04.5\end{array}$ & $\begin{array}{c}0.18 \\
05.2\end{array}$ & $\begin{array}{c}0.08 \\
08.3\end{array}$ & $\begin{array}{c}0.64 \\
06.1\end{array}$ \\
\hline Total & 06.5 & 06.5 & 06.0 & $\mathbf{8 8 . 3}$ & 07.5 & 07.1 & 07.7 & 08.3 & 08.0 \\
\hline \multicolumn{10}{|c|}{ Catlons based on 8 oxygens } \\
\hline $\mathbf{M g}$ & 0.443 & 0.408 & 0.411 & 0.451 & 0.380 & 0.420 & 0.412 & 0.307 & 0.397 \\
\hline $\begin{array}{l}\text { Al } \\
\text { SI }\end{array}$ & $\begin{array}{l}0.230 \\
0.000\end{array}$ & $\begin{array}{l}0.350 \\
0.233\end{array}$ & $\begin{array}{l}0.352 \\
0.261\end{array}$ & $\begin{array}{l}0.200 \\
0.000\end{array}$ & $\begin{array}{l}0.270 \\
0.000\end{array}$ & $\begin{array}{l}0.255 \\
0.000\end{array}$ & $\begin{array}{l}0.270 \\
0.000\end{array}$ & $\begin{array}{l}0.316 \\
0.000\end{array}$ & $\begin{array}{l}0.418 \\
0.000\end{array}$ \\
\hline $\mathrm{Ca}$ & 0.007 & 0.040 & 0.047 & 0.006 & 0.011 & 0.015 & 0.007 & 0.003 & 0.002 \\
\hline $\mathbf{T I}$ & 1.109 & 1.003 & 1.038 & 1.273 & 1.207 & 1.268 & 1.286 & 1.254 & 1.100 \\
\hline $\mathbf{V}$ & 0.031 & 0.020 & 0.027 & 0.042 & 0.043 & 0.040 & 0.040 & 0.007 & 0.011 \\
\hline Cr & 0.001 & 0.001 & 0.001 & 0.003 & 0.003 & 0.003 & 0.004 & 0.000 & 0.000 \\
\hline Mn & 0.030 & 0.025 & 0.025 & 0.020 & 0.020 & 0.028 & 0.020 & 0.042 & 0.030 \\
\hline $\mathrm{Fe}$ & 3.857 & 3.480 & 3.566 & 4.000 & 3.836 & 3.781 & 3.885 & 4.104 & 3.080 \\
\hline
\end{tabular}

me $=$ core of small crystal

$R=$ rim of larger crystal

$\mathrm{C}=$ core of larger erystal 


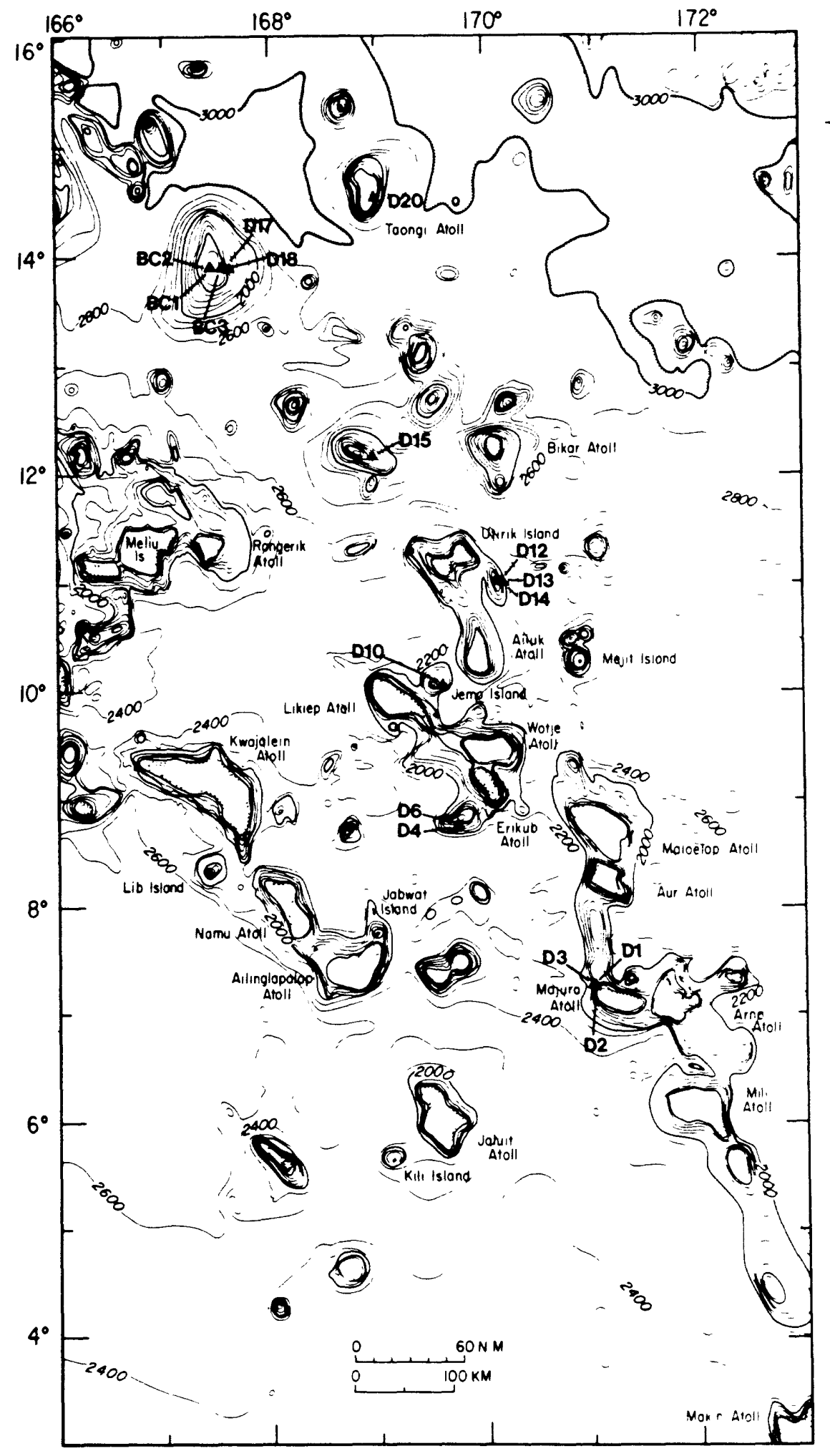

Figure 1. Bathymetric map of the Ratak chain of the Marshall Islands (from Chase et al., 1971) showing dredge locations. The contour interval is $200 \mathrm{~m}$. 


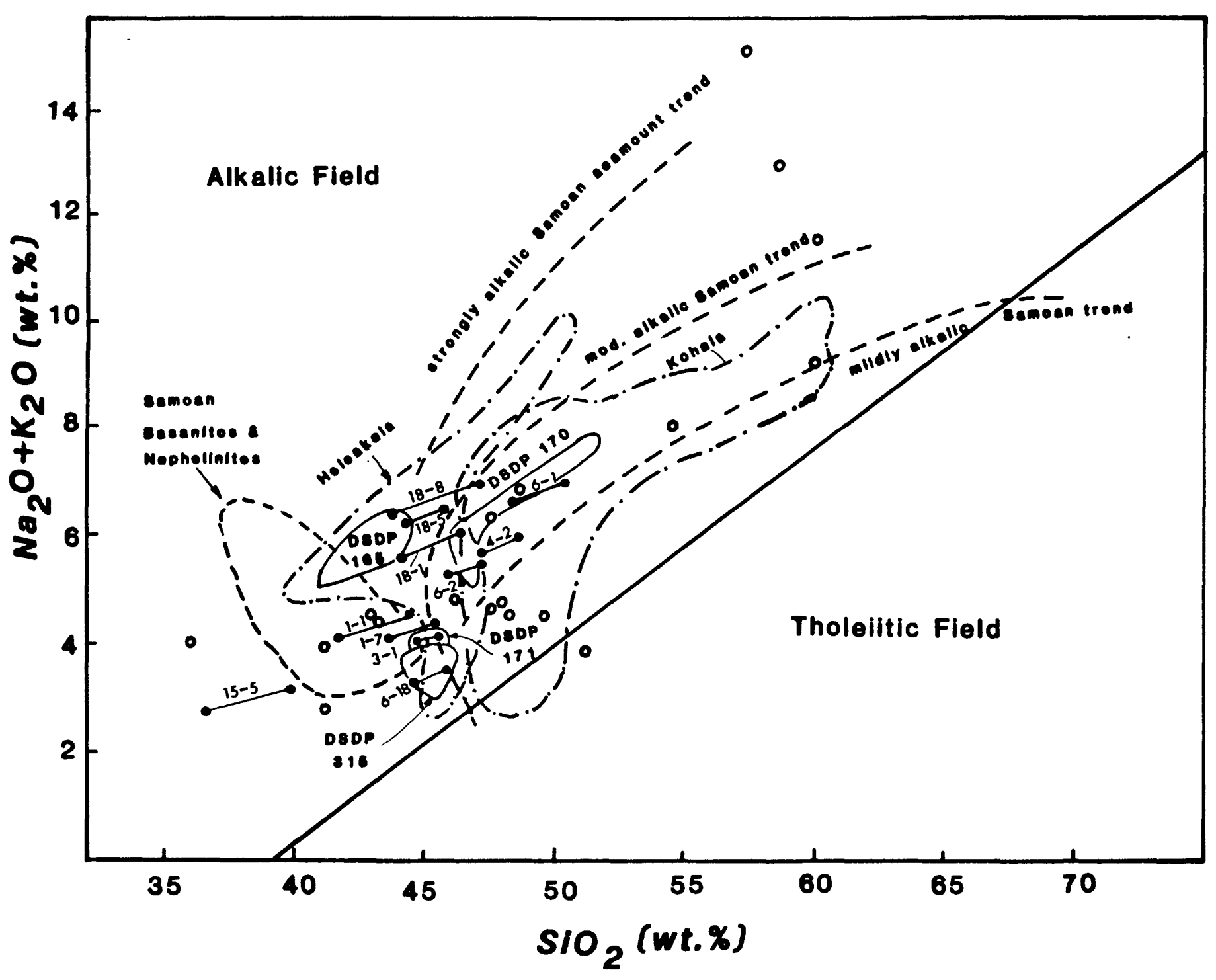

Figure 2. Alkalies versus silica plot for lavas dredged from the Marshall Islands (solid circles), line dividing alkalic from tholeiitic field from Macdonald and Katsura (1964). All samples plot in the alkalic field. Figure modified from Natland (Fig. 3, 1976) showing trends for Samoan volcanism and fields for basaltic rock from DSDP sites 315, 170, 171, and 165 as shown in that figure. Line Island compositions (open circles) are also from Natland (1976) but only dry-reduced data points are shown. Field for post-caldera alkalic lavas of Haleakala and Kohala differentiation trend from Macdonald (1968). 


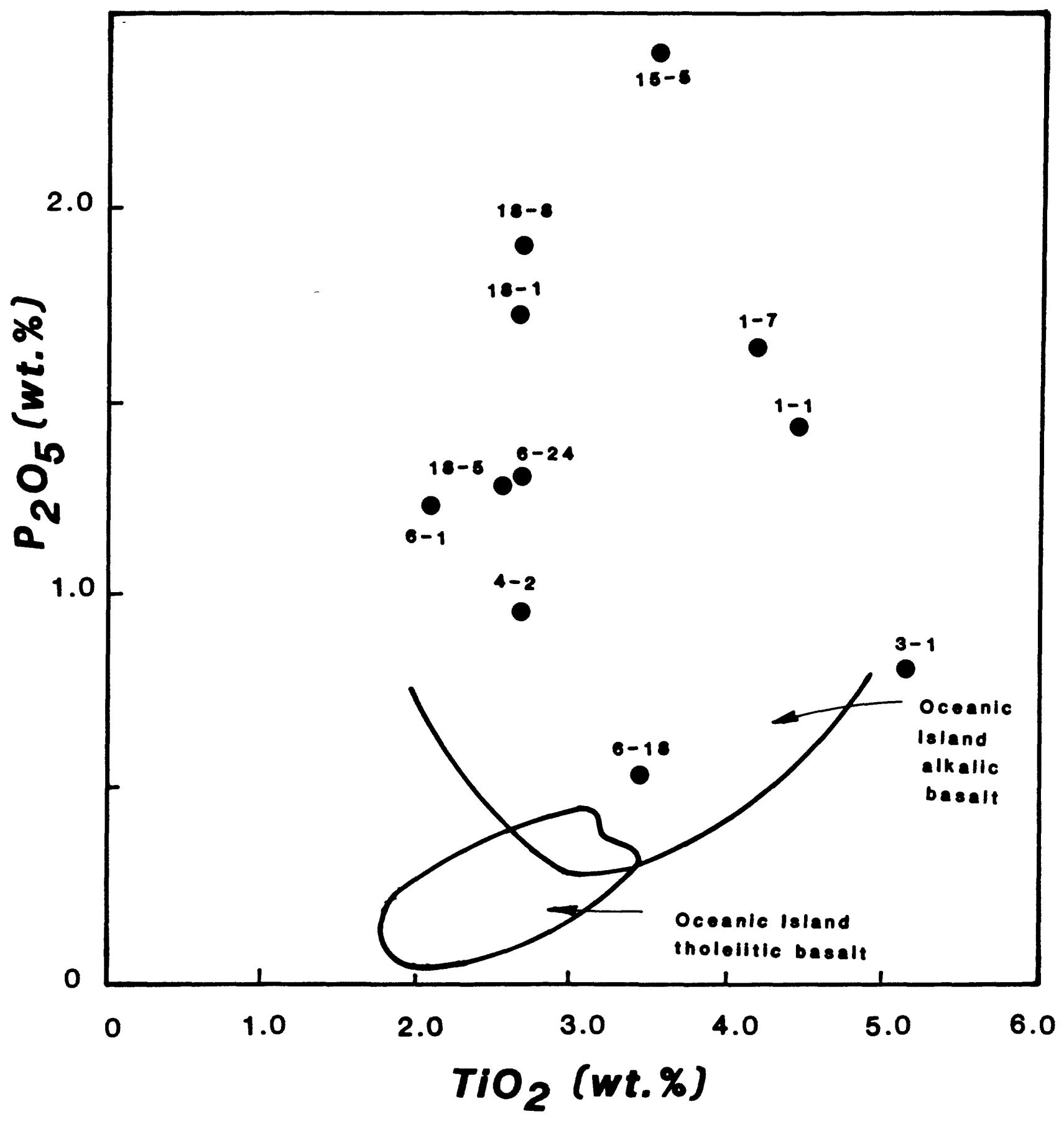

Figure 3. $\mathrm{P}_{2} \mathrm{O}_{5}$ versus $\mathrm{TiO}_{2}$ plot for dredged lavas. Fields of oceanic island tholeiite and alkalic basalt from Bass et al. (1973). The scatter is probably largely due to alteration and addition of $\mathrm{P}_{2} \mathrm{O}_{5}$. 


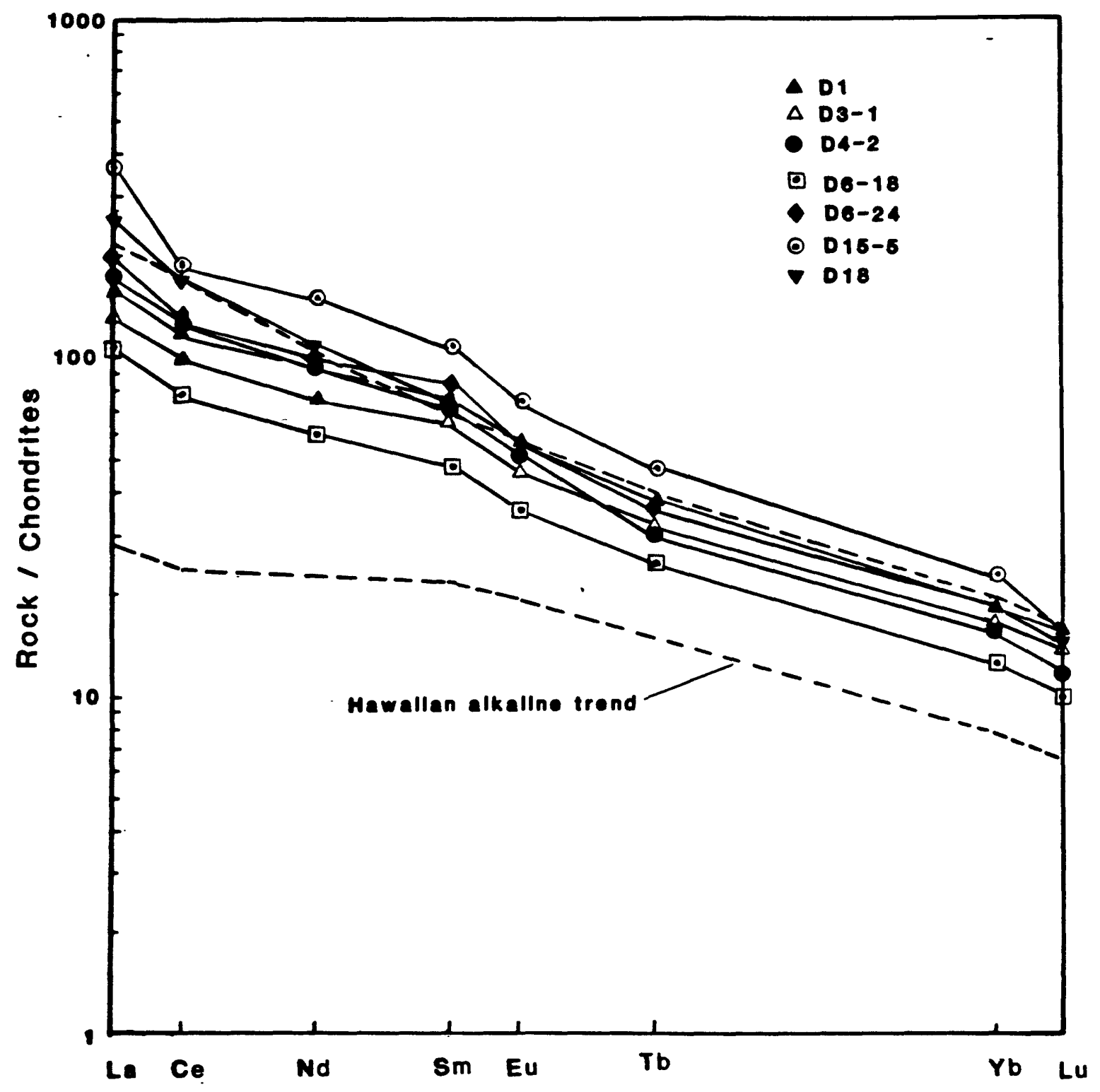

Figure 4. Chondrite normalized rare earth element patterns for dredged lavas. Field of Hawaiian alkalic REE patterns shown for comparison is from Basaltic Volcanism Project (1981). Note that Hawaiian alkaline series includes compositions as evolved as mugearites. Compositions of dredge 1 as well as dredge 18 have been averaged. REE patterns of Marshall Island lavas show abundances and LREE over HREE enrichment typical of differentiated alkalic lavas. They appear somewhat more enriched than comparably evolved Hawaiian lavas. 


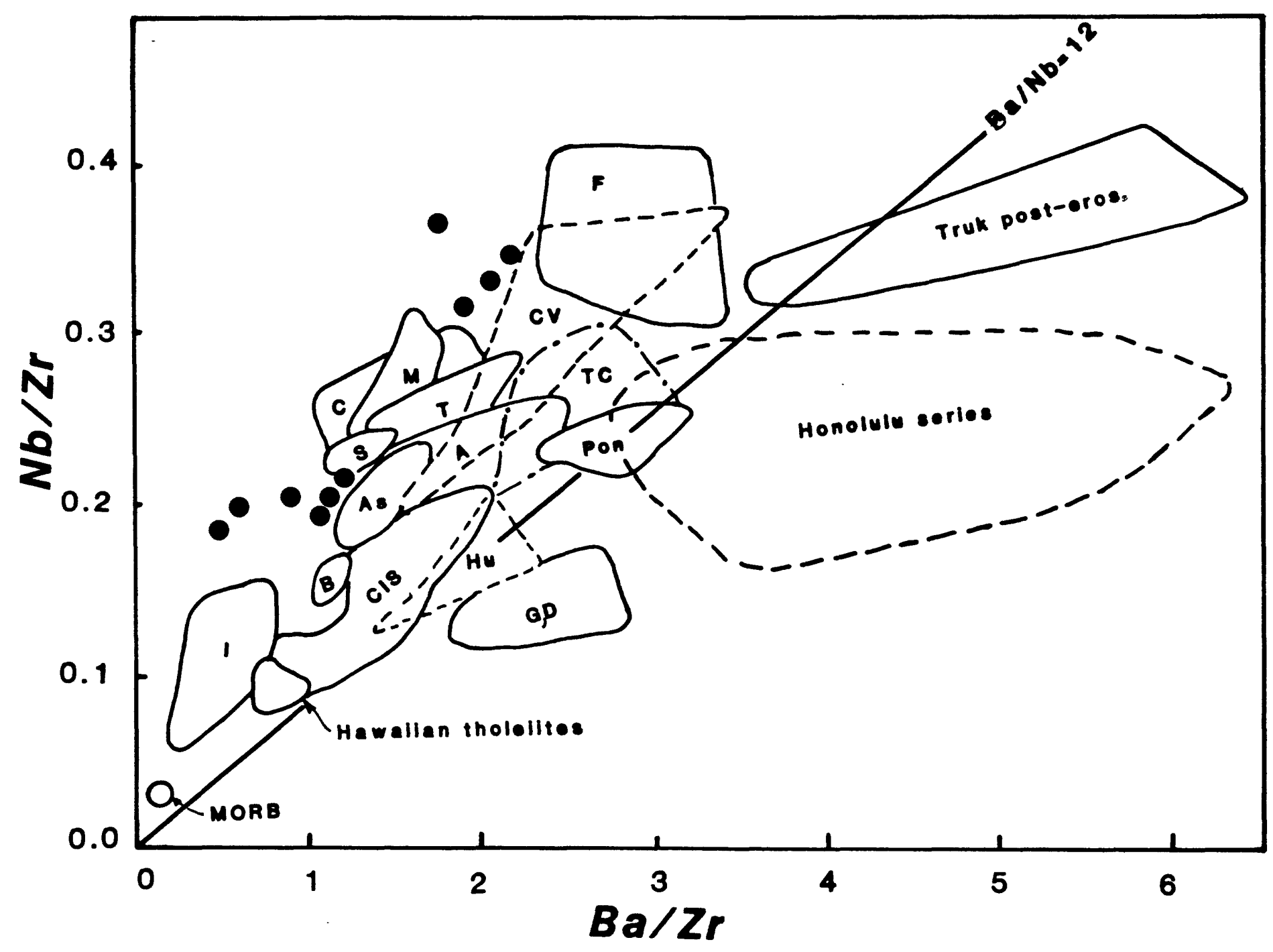

Figure 5. Plot of $\mathrm{Nb} / \mathrm{Zr}$ versus $\mathrm{Ba} / \mathrm{Zr}$ shows the Marshall Island lavas in comparison with other alkalic lavas from islands in the Pacific and South Atlantic Ocean. Figure modified from Mattey (Fig.10, 1982). I, Iceland; CIS, Caroline Islands shield lavas; Pon, Ponape, post-erosional; Hu, Hualalai; B, Bouvet; AS, Ascencion; A, Azores; S, St.Helena; C, Canaries; M, Madeira; T, Trinidad; CV, Cape Verde; F, Flores; TC, Tristan da Cunha; $\mathrm{G}, \mathrm{D}$, Gough and Discovery. Marshall Island lavas have higher $\mathrm{Nb} / \mathrm{Zr}$ ratios at comparable $\mathrm{Ba} / \mathrm{Zr}$ than Hawaiian lavas, and show greater similarity with Atlantic Ocean island lavas than with those from the Pacific Ocean. 